\title{
Multidiszciplináris könyvtárosképzés és multifunkciós egyetemi könyvtár a tudásalapú gazdaság kontextusában*
}

\section{Hatások és ellenhatások}

„Ha egy tárgy egy másik tárgyat húz vagy nyom, akkor a második tárgy az elsőt ugyanolyan mértékben húzza vagy nyomja" - fogalmazza meg Newton III. törvényében. ${ }^{1}$ Dolgozatunkban erre az alaptételre támaszkodva kívánjuk igazolni az egyetemi könyvtárak és a felsőfokú könyvtárosképzés egymásra utaltságából fakadó, kölcsönösen támogató szakmai dinamizmusát, ahhoz az oktatás és a tudományos kutatás részéről biztosított muníciót.

A könyvtárosság gyakorlatias hivatás, így a szakma - a mindenkori kompetenciaigényekhez igazodva - táplálja a képzést. Nincs új a nap alatt: a jövő a múltra épül a képzésben is. A 2019-ben 70. jubileumát ünneplő hazai egyetemi könyvtárosképzés ${ }^{2}$ tevékenységével kapcsolatban a könyvtári rendszer már a kezdetektől megfogalmazott elvárásokat. A Könyvtáros 1954. évi 4. számából erre két beszédes közleménycím: Magasabb színvonalú könyvtárosképzést! ${ }^{3}$ és Gyakorlatiasabb könyvtárosképzést! ${ }^{4}$ Több évtized elteltével, a folyamatos környezeti változások, különösen a tudásalapú gazdaság és társadalom, ${ }^{5}$ a digitális fejlesztések, a mesterséges intelligencia ${ }^{6}$ szorításában ez a jelenség ma is megfigyelhető - olykor erőteljesebben, olykor diplomatikusabban és kevésbé határozottan.

\footnotetext{
*A tanulmány a Bolyai János Kutatási Ösztöndíj támogatásával készült.

${ }^{1}$ Szegedi Péter: Fizikatörténeti szöveggyüjtemény. Digitális Tankönyvtár. 2013. https://regi. tankonyvtar.hu/hu/tartalom/tamop412A/2011-0064_69_fizikatorteneti_szoveggyujtemeny/ $\operatorname{ar} 01 \mathrm{~s} 02 . \mathrm{html}$

${ }^{2}$ Fodor János: Konferencia és ünnep. Valóságos könyvtár - könyvtári valóság IV. konferencia az Eötvös Loránd Tudományegyetemen. = Könyvtári Figyelö, 30. évf. 2020. 1. sz. 41-53. p. https://epa.oszk.hu/00100/00143/00359/pdf/EPA00143_konyvtari_figyelo_2020_01_041-053.pdf; VKKV konferencia. ELTE LIS: http://lis.elte.hu/vkkv

${ }^{3}$ Balázs Sándor: Magasabb színvonalú könyvtárosképzést! = Könyvtáros, 4. évf. 1954. 4. sz. 28. p.

${ }^{4}$ Gyakorlatiasabb könyvtárosképzést! = Könyvtáros, 4. évf. 1954. 4. sz. 29. p.

${ }^{5}$ A tudásalapú gazdaság és társadalom. Szerk. Báger Gusztáv. Budapest, Állami Számvevőszék. 2008. https://www.asz.hu/storage/files/files/Szakmai\%20kutat\%C3\%A1s/2008/t268. pdf?download=true; A tudásalapú társadalom kialakulása Magyarországon. Szerk. Tamás Pál. Budapest, ÚMK. 2005. (Stratégiai kutatások - Magyarország 2015, 6.) https://szociologia.tk.mta.hu/ uploads/files/archive/6_tudasalapu_tarsadalom.pdf

${ }^{6}$ Digitális Jólét Program. Mesterséges Intelligencia Koalíció. https://digitalisjoletprogram.hu/ hu/tartalom/mesterseges-intelligencia-koalicio
} 
A könyvtárosképzés - eddigi müködése során - mindig prioritásként kezelte e szimbiotikus kapcsolatot azzal, hogy természetszerüen az oktatás irányából is érzékelhetők a multifunkciós könyvtári rendszer, a gyakorlat problémái, amik - egymást gerjesztően - kihatnak mindkét oldal tevékenységére. A két fél közti folyamatos és egyenrangú, kölcsönös tiszteleten alapuló, megoldáscentrikus diskurzus tehát nélkülözhetetlen. Ennek jórészt az egyetemi könyvtárakra koncentráló aspektusait tárjuk fel az Eötvös Loránd Tudományegyetem Bölcsészettudományi Kar (ELTE BTK) Könyvtár- és Információtudományi Intézetének oktatási-kutatási törekvéseit fókuszba helyezve, s viszonyítva a nemzetközi tendenciákhoz. Munkánkat szervesen kiegészíti $A$ könyvtár-és információtudományi képzés ökológiája című korábbi, átfogó megközelítésủ összefoglalásunk. ${ }^{7}$

\section{Globális és lokális mozgástér}

Látni kell, hogy a következö környezeti elemek, legyenek azok nemzetközi trendek vagy hazai szabályozók, külső vagy belső tényezők, determinálják mind a magyarországi könyvtári rendszer, mind pedig a könyvtárosképzés lehetőségeit:

1. a nemzetközi és a hazai felsőoktatási környezet, a korábbi föiskolai és egyetemi szinteket felváltó, 2006-tól bevezetett bolognai, ún. osztott szerkezetü képzés sajátosságai;

2. a könyvtár- és információtudomány mint diszciplína eltérő megítélése itthon és a nemzetközi tudományos életben;

3. a könyvtári-információszolgáltatási technológia rohamos fejlődése;

4. a szakma egész világon zajló útkeresése, újradefiniálása;

5. a könyvtárosok nemzetközi megítélése és hazai presztízse, bérezése közti szakadék;

6. a tanfolyamok dotálása, a hazai felsőfokú könyvtárosképzés kimaradása a jelentős ágazati projektekből és források felhasználásából;

7. a magyarországi könyvtári rendszer érdekérvényesítő képességének, az egyes könyvtártípusok összefogásának különböző mértéke;

8. az Országos Könyvtári Rendszer (OKR) müködésére irányulóan megfogalmazódó fokozott várakozás, egyúttal a nemzeti könyvtár fejlesztésének kérdése;

9. az országos könyvtári stratégiát helyettesítő Közgyüjteményi Digitalizálási Stratégia (KDS) és a benne nevesített Nemzeti Adattár Projekt $(N A P)$ adta támpontok;

10. a COVID-19 világjárvány hatására új távolléti müködési mechanizmusok a könyvtárakban és az egyetemeken.

${ }^{7}$ Kiszl Péter: A könyvtár- és információtudományi képzés ökológiája. = Könyvtári Figyelö, 30. évf. 2020. 1. sz. 9-40. p. https://epa.oszk.hu/00100/00143/00359/pdf/EPA00143_konyvtari_ figyelo_2020_01_009-040.pdf 
A könyvtárosképzésnek ebben a közegben kell eredményeit felmutatnia, versenypiaci viszonyok között minden tanulni vágyó korosztály számára vonzó pályaalternatívát kínálnia, valamint a munkaadók igényeit kiszolgáló, időtálló tudást biztosítania.

\section{Szakmai vezérfonalak}

A hazai felsőoktatási könyvtárak jövőképét az Egyetemi Könyvtárigazgatók Kollégiuma (EKK) által jegyzett, A felsőoktatási könyvtárak stratégiai fejlesztési irányai 2018-2023 címủ dokumentum rögzíti, ${ }^{8}$ illetve az ELTE Egyetemi Könyvtár és Levéltár (EKL) Hagyományok és kihívások konferenciasorozatának ${ }^{9}$ elöadásai 2011-től évről évre követik a témában. A magyar nyelvü kiindulópontok mellett ugyanolyan fontosnak tartjuk a mértékadó nemzetközi szakfolyóiratok (pl. College \& Research Libraries, Communications in Information Literacy, The Journal of Academic Librarianship) európai és amerikai trendeket elemző közelmúltbéli szakcikktermését is áttekinteni, azokból - terjedelmi okokból eröteljesen válogatva, csak - néhány figyelemre méltó megállapítást kiemelni.

A Sheffieldi Egyetemi Könyvtár (University of Sheffield Library) 2018-as kutatása alapján a jövőt meghatározó környezet hajtóereje négy kategóriába sorolható:

1. digitalizáció,

2. hallgatói tapasztalatok,

3. diverzifikáció,

4. együttmüködés.

Az egyetemi könyvtárak 21. századi hasznosságának kimutatására ún. értékkereket alkottak, melynek elemei:

- Motiváció: A könyvtár motiválhatja, inspirálhatja a kutatást, a tudásteremtést.

- Hitelesség: A könyvtár biztosíthatja a tudásteremtés folyamatának hitelességét, minőségét.

- Kényelem: A könyvtár könnyebbé teszi az intellektuális felfedezést és az ismeretek létrehozását.

- Hatékonyság: A könyvtár kevésbé költségessé teszi a tudásteremtést. ${ }^{10}$

${ }^{8}$ Antal Istvánné et al.: A felsőoktatási könyvtárak stratégiai fejlesztési irányai 2018-2023 http://ekk.org.hu/sites/default/files/EKFJ_2018_2023a.pdf; Nagy Zsuzsanna - Karácsony Gyöngyi: A kutatás és az oktatás innovációs csomópontjai: a felsőoktatási könyvtárak stratégiai fejlesztési irányai 2018-2023. = Tudományos és Müszaki Tájékoztatás, 66. évf. 2019. 7-8. sz. 420-429. p. https://tmt.omikk.bme.hu/tmt/article/view/12334

${ }^{9}$ A konferenciák előadásaiból készült tanulmánykötetek az ELTE EDIT-ben: https://edit.elte. hu/xmlui/handle/10831/34233

${ }^{10}$ Boyce, Gavin et al.: Visions of Value: Leading the Development of a View of the University Library in the 21 st Century. $=$ The Journal of Academic Librarianship, 45. vol. 2019. 5. no. https://doi.org/10.1016/j.acalib.2019.102046 
Egy nagyszabású, 2017-2018 folyamán zajlott amerikai felmérés feltárta a felsőoktatási könyvtárak által preferált ismereteket, készségeket és képességeket is. Az eredmények erősen hangsúlyozzák:

1. az interperszonális kommunikációs készségeket $(+)$,

2. a szakmai etika ismeretét,

3. az íráskészséget $(+)$,

4. a keresési képességeket (-),

5. a csapatmunkára való alkalmasságot,

6. az információforrások értékelését és kiválasztását (-),

7. a kulturális kompetenciákat,

8. az ügyfélszolgálati készségeket (-),

9. a különböző közösségekkel való interakciós készséget (+),

10. a reflektív gyakorlatot a diverzitás és az inklúzió kezelésében,

11. a referensz interjú/kérdés megoldásának jelentőségét (-).

Ezekben szignifikáns különbségek is jelentkeztek a tudományos könyvtárakban dolgozók elvárásai (1.+), valamint a más területen foglalkoztatott könyvtárosok, információs szakemberek (1. -) között. ${ }^{11}$

Az egyetemi könyvtárak a felsőoktatási karok fejlesztői - ezt támasztja alá a Purdue Egyetem (Purdue University) részvételével lebonyolított IMPACT projekt. A fenomenográfiai alapú interjúelemzési módszerrel négy kategóriában tárták fel az egyetemi könyvtárosok szerepeit:

1. Csatlakozó: az oktatókat összekapcsolja a pedagógiai vagy technológiai szakemberekkel.

2. Megbízó: az oktatókat irányítja a kurzus kialakításán keresztül.

3. Munkatárs: kölcsönösen elönyös kapcsolatot ápol az oktatókkal.

4. Fejlesztő: oktatókat képez, hogy átalakítsák tanítási megközelítésüket. ${ }^{12}$

Az egyetemi könyvtárosképzés nélkülözhetetlenségét tanúsítja az Amerikai Könyvtárak Szövetségéhez (American Library Association - ALA) kötődő 2018as megkérdezés, amely kimutatta, hogy az USA tudományos (egyetemi és szak) könyvtárvezetőinek többsége rendelkezik szakirányú mesterdiplomával, és a könyvtárvezetői munkához szükségesnek tartja annak meglétét. ${ }^{13}$ Ezt erősíti

\footnotetext{
${ }^{11}$ Saunders, Laura: Core Knowledge and Specialized Skills in Academic Libraries. $=$ College \& Research Libraries, 81. vol. 2020. 2. no. 288-311. p. https://doi.org/10.5860/crl.81.2.288

${ }^{12}$ Flierl, Michael - Maybee, Clarence - Fundator, Rachel: Academic Librarians' Experiences as Faculty Developers: A Phenomenographic Study. = Communications in Information Literacy, 13. vol. 2019. 2. no. 184-204. p. https://doi.org/10.15760/comminfolit.2019.13.2.4

${ }^{13}$ Michalak, Russell - Rysavy, Monica D.T. - Dawes, Trevor A.: What Degree Is Necessary to Lead? ARL Directors' Perceptions. $=$ College \& Research Libraries, 80. vol. 2019. 6. no. 752765. p. https://doi.org/10.5860/crl.80.6.752
} 
meg az Arizonai Egyetem Könyvtárainak (University of Arizona Libraries) gyakorlata is, ahol az intézmények számára elsődleges szempont, hogy az újonnan felvett szakemberek könyvtár- és információtudományi mesterszakos végzettséggel rendelkezzenek. ${ }^{14}$

Az egyetemi könyvtáraknak olyan új szerepekkel is meg kell birkózniuk, mint például a hallgatók pénzügyi mủveltségének fejlesztése. Az ALA felsőoktatási és tudományos könyvtári tagozatának (Association of College \& Research Libraries, ACRL) 2013-2014 közötti elnöki programja a pénzügyi kultúra egyetemi könyvtárak általi edukációjának előmozdítását helyezte középpontba, aminek folyományaként egy nagyszabású felmérés is készült. ${ }^{15}$ Úttörö kezdeményezésként hivatkozhatunk a Pennsylvaniai Állami Egyetem könyvtári rendszerén (Pennsylvania State University Libraries) belül, ún. peer-to-peer elven müködő Hallgatói Pénzügyi Oktatási Központra (Student Financial Education Center). ${ }^{16}$

Szakirodalmi áttekintésünk végén utalunk a Libri hasábjain 2018-ban From Divergence to Convergence in Hungarian Librarianship: Towards a Common Digital Platform címmel megjelent tanulmányunkra, melyben átfogóan vizsgáltuk a hazai könyvtári rendszer sajátos fejlődési ívét és fejlesztési irányait, beleértve a felsőoktatási és tudományos könyvtári vonatkozásokat is. ${ }^{17}$

Az egyetemi könyvtárakhoz köthető valamennyi innováció feltételezi a könyvtárosok (elsősorban könyvtárvezetők) pénzügyi jártasságának meglétét, korszerü piacgazdasági szemléletét, kommunikációs és informatikai felkészültségét, valamint rugalmas alkalmazkodási képességét.

\section{Felsőfokú könyvtárosképzés Magyarországon}

2020-ban a Debreceni Egyetem (DE), az ELTE, az Eszterházy Károly Egyetem (EKE), a Nyíregyházi Egyetem (NYE), a Pécsi Tudományegyetem (PTE) és a Szegedi Tudományegyetemen (SZTE) hirdetett könyvtár- és információtudományi diszciplináris szakokat. ${ }^{18} \mathrm{~A}$ normál és pótfelvételi eljárásban felvettek számát

${ }^{14}$ Oliver, Jeffrey C. et al.: Data Science Support at the Academic Library. = Journal of Library Administration, 59. vol. 2019. 3. no. 241-257. p. https://doi.org/10.1080/01930826.2019.1583015

${ }^{15}$ Reiter, Lauren - Ford, Bronson: Library Support for Student Financial Literacy: A Survey of Librarians at Large Academic Institutions. = College \& Research Libraries, 80. vol. 2019. 5. no. 618-637. p. https://doi.org/10.5860/crl.80.5.618

${ }^{16}$ Reiter, Lauren: Financial Literacy and the Academic Library: Exploring the Peer-to-Peer Approach. $=$ Journal of Business \& Finance Librarianship, 20. vol. 2015. 1-2. no. 54-65. p. https:// doi.org/10.1080/08963568.2015.977732

${ }^{17}$ Kiszl, Péter - Radó, Rita - Hubay, Miklós Péter: From Divergence to Convergence in Hungarian Librarianship: Towards a Common Digital Platform. = Libri, 68. vol. 2018. 4. no. 315329. p. https://doi.org/10.1515/libri-2018-0049

${ }^{18}$ A Nyíregyházi Egyetem alapképzés (BA) folytatására jogosult, a többi intézmény emellett mesterképzés (MA) és könyvtárostanár osztatlan tanárképzési szak indítására is rendelkezik akkreditációval. 
az 1. és 2. ábrák mutatják intézményenkénti bontásban (a Nyíregyházi Egyetemen nem indult el az alapszak).

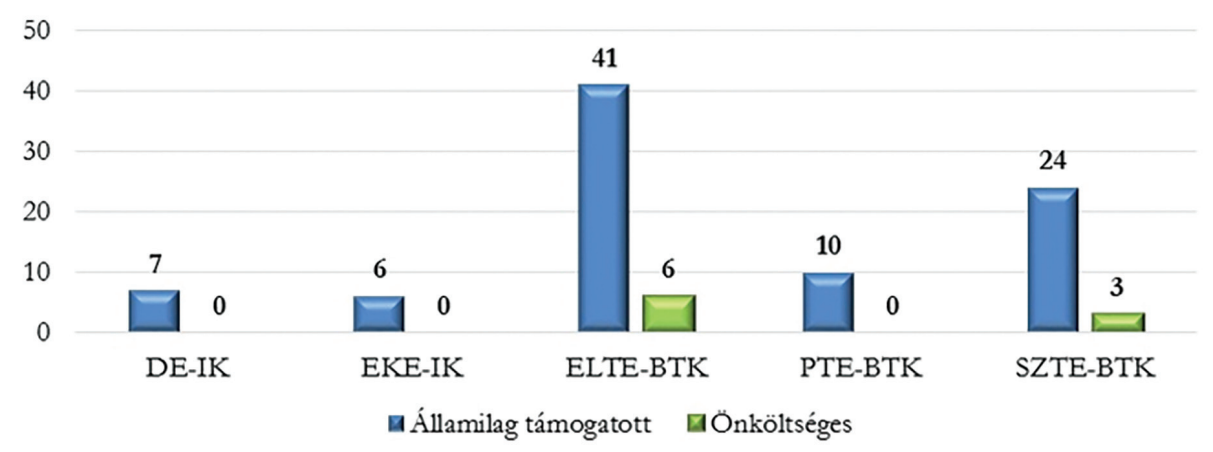

1. ábra. Informatikus könyvtáros alapképzés (BA) nappali és levelezö tagozatára felvett hallgatók száma 2020-ban. (A felvi.hu adatai alapján készítette: Németh Katalin.)

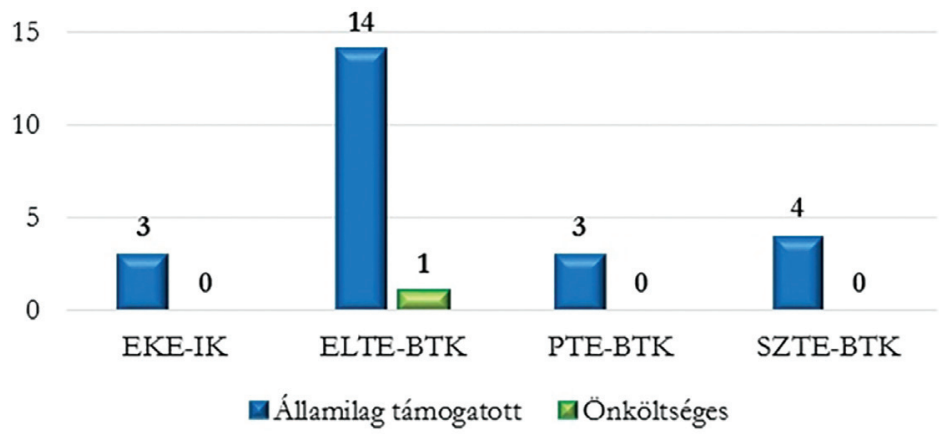

2. ábra. Könyvtártudomány mesterképzés (MA) nappali és levelezö tagozatára felvett hallgatók száma 2020-ban. (A felvi.hu adatai alapján készítette: Németh Katalin.)

Az ún. osztott rendszerü, 2006-ban indult, társadalomtudományi besorolású képzés ${ }^{19}$ jelenlegi szerkezetét már többször ismertettük, ${ }^{20}$ ehelyütt csak jelezzük az egymásra épülő szinteket:

${ }^{19}$ A társadalomtudományi besorolás, valamint a képzőhelyek bölcsészettudományi (ELTE, PTE, SZTE) vagy informatikai (DE, EKE) kari tagozódása jól jelzi a könyvtár- és információtudomány interdiszciplináris jellegét.

${ }^{20}$ Pl.: Kiszl Péter: „Tessék választani!” Informatikus könyvtárosok mesterképzésen innen, alapképzésen túl. = Könyvtári Levelezö/lap, 20. évf. 2008. 12. sz. 5-8. p. http://www.epa.oszk. hu/00300/00365/00085/pdf/00085.pdf; Kiszl Péter: Ízlik-e a bolognai? A többciklusú informatikus könyvtárosképzés eddigi tapasztalatai. = Tudományos és Müszaki Tájékoztatás, 57. évf. 2010. 1. sz. 3-14. p. http://tmt.omikk.bme.hu/tmt/article/view/7651. Az ELTE BTK Könyvtártudományi doktori programjáról bővebben: Kiszl Péter: Kutatás és innováció - kompetenciafejlesztés 
- alapképzés (6 félév, informatikus könyvtáros Bachelor - BA - végzettség);

- mesterképzés (4 félév, informatikus könyvtáros Master - MA - végzettség);

- könyvtár- és információtudományi doktori ( $\mathrm{PhD})$ képzés (4+4 félév).

Osztatlan tanárképzésben végezhető el a könyvtárostanár közismereti szakpártag (10 vagy 11 félév, rövid ciklusú változatokban 2 vagy 4 félév) ${ }_{,}^{21}$ valamint felvehető az informatikus könyvtáros minor (más BA-szak hallgatói számára szakirány vagy specializáció helyetti 50 kredites modul), és a zenei kultúra alapszakon belül a zenei könyvtáros specializáció. ${ }^{22}$

Az alap- és mesterképzést meghatározó képzési és kimeneti követelményeket (KKK) széles körü szakmai konszenzussal, az érintett képzőintézmények mellett a Magyar Könyvtárosok Egyesülete (MKE), az Informatikai és Könyvtári Szövetség (IKSZ), az Egyetemi Könyvtárigazgatók Kollégiuma (EKK), valamint a Hallgatói Önkormányzatok Országos Konferenciája (HÖOK) képviselőivel együtt - a nemzetközi trendeket és a munkaeröpiaci igényeket figyelembe véve, rugalmas, egyetemekre szabható keretben - alkottuk meg 2015-ben, létrehozva a Könyvtár- és Információtudományi Képzések Kollégiumát (KIKK). ${ }^{23} \mathrm{~A}$ munka során szem előtt tartottuk a Könyvtár- és Információtudományi Oktatás és Kutatás Európai Szövetsége (European Association for Library \& Information Education and ResearchEUCLID) tantervfejlesztési irányelveinek ${ }^{24}$ javaslatait a $\mathrm{BA}, \mathrm{MA}$ és a $\mathrm{PhD}$ egymásra épülése érdekében. A kialakítás során igyekeztünk nem tantárgyszinten szabályozni, hanem az aktuális tartalmakat magukba foglaló tantárgyakra intézményi hatáskörben lehetőséget biztosító témaköröket (és kreditsávokat) meghatározni:

a könyvtár- és információtudományi doktori képzésben. = Szakmai ismeretek és készségek - átalakuló hivatás. Válogatott könyvtártudományi tanulmányok. Szerk. Barátné Hajdu Ágnes. Budapest, Magyar Könyvtárosok Egyesülete. 2020. https://doi.org/10.46280/KOMPKONF.2020. Kiszl [megjelenés alatt]

${ }^{21}$ Barátné Hajdu Ágnes - Németh Katalin - Boda Gáborné Köntös Nelli: Az osztatlan könyvtárostanár mesterképzési szak indításának kihívásai az ELTE BTK Könyvtár- és Információtudományi Intézetében. $=$ Tanulmányok a tudós tanárképzés mühelyeiből. Szerk. Károly Krisztina - Perjés István. Budapest, ELTE Eötvös Kiadó. 2015. 115-131. p. http://www.eltereader.hu/ media/2016/01/Tanulmanyok_READER.pdf

${ }^{22}$ Kiszl Péter - Németh Katalin: Diszciplínák metszéspontjában: zenei könyvtárosok képzése az Eötvös Loránd Tudományegyetemen. = Parlando, 62. évf. 2020. 8. sz. http://www.parlando. hu/2020/2020-3/Kiszl_Peter-Nemeth_Katalin.pdf

${ }^{23}$ Kiszl Péter: Újratervezés a könyvtárosképzésben. = Tudományos és Műszaki Tájékoztatás, 62. évf. 2015. 11-12. sz. 399-414. p. http://tmt.omikk.bme.hu/tmt/article/view/605; Kiszl Péter: Könyvtártudomány 2017-től - a katedra szemszögéböl. = Könyv és Nevelés, 19. évf. 2017. 1. sz. 26-37. p. http://folyoiratok.ofi.hu/sites/default/files/journals/ken_2017-1_online.pdf

24 EUCLID Guidelines for Curriculum Development. http://euclid-lis.eu/wp-content/ uploads/2014/03/euclid-guidelines-cur-dev.pdf 
BA (6 félév/180 kredit, elmélet-gyakorlat aránya: gyakorlatorientált):

- társadalom- és bölcsészettudományok (10-25 kredit)

- könyvtártan és információszervezés (25-40 kredit)

- menedzsment ismeretek (5-20 kredit)

- informatika (10-25 kredit)

- kommunikációs ismeretek (5-20 kredit)

- szakmai gyakorlat: min. 300 óra (15 kredit)

- szabadon választható tantárgyak (9 kredit)

- diplomamunka (10 kredit).

MA (4 félév/120 kredit, elmélet-gyakorlat aránya: kiegyensúlyozott):

- társadalom- és bölcsészettudományok (5-15 kredit)

- tartalommenedzsment, tudásgazdálkodás (10-25 kredit)

- tudománymetria, kutatástámogatás (5-15 kredit)

- gazdasági és vezetési ismeretek, szervezetfejlesztés (5-15 kredit)

- szaknyelvi ismeretek (4-10 kredit)

- szakmai gyakorlat: min. 150 óra (10 kredit)

- szabadon választható tantárgyak (6 kredit)

- diplomamunka (20 kredit).

A munkaerőszükséglet kielégítése valamennyi könyvtártípus számára felsőoktatási (verseny)környezetben és nem tanfolyami keretek között történik. Az intézményeknek meg kell felelniük a Magyar Felsőoktatási Akkreditációs Bizottság $(M A B)$ által támasztott szakindítási és szakalapítási követelményeknek ${ }^{25}$ (beleértve az oktatókra vonatkozó minimumkövetelményeket is), a felsőoktatási szabályozóknak és a szakmai elvárásoknak is. Belátható, hogy ez minimálisan kettős (felsőoktatási és könyvtári rendszer) kötődést feltételez, ami folyton változó világunkban - az adott mozgástér szükségszerü betartása érdekében - kompromisszumos megoldások felé irányítja, és állandó képzésfejlesztésre, különösen a hálótervek rendszeres felülvizsgálatára, könyvtáros szakemberekkel, specialistákkal, doktoranduszokkal történő folyamatos kooperációra sarkallja a képzőhelyeket. Dinamikus elemek lehetnek a felsőoktatásban, amelyekben kívánatos a külső szakemberek szerepvállalása:

- workshopok;

- vendégelőadások;

- labor-, stúdió- és külső helyszíni projekt-, illetve mühelymunkák;

- szakmai gyakorlatok, kritikus gondolkodást és innovációt támogató feladatok stb. ${ }^{26}$

${ }^{25}$ MAB Dokumentumtár. https://www.mab.hu/dokumentumtar

${ }^{26}$ Vö.: Lectures, Workshop Activities, Studio Time, Seminar Discussions, Guest Speakers, Critique and Feedback Sessions. Említi: Clarke, Rachel Ivy - Bell, Steven: Transitioning from the 
Nem lehet azonban elégszer hangsúlyozni: más a tanfolyamok és más a felsőoktatási képzések célja. A felsőoktatásban megszerzett alapokra, elméleti és gyakorlati ismeretekre, tudományos készségekre stb. építhetnek az élethosszig tartó tanulást támogató mindenkori továbbképzések az aktuális innovációknak és munkahelyi elvárásoknak megfelelően. Hogyan is tudná ma, 2020-ban előre meghatározni azt egy képzőhely, hogy az alapkompetenciák mellett milyen továbbiakra lesz szüksége 2040-ben egy könyvtárosnak? Ezek fejlesztése a húsz év múlva induló továbbképzések feladata kell, hogy legyen. Kulcsfontosságú például, hogy mit tud egy friss mesterdiplomával rendelkező könyvtáros szakember, de ugyanolyan lényeges, hogy munkája végzése során folyamatosan naprakész tud-e maradni.

\section{Könyvtárosképzés az ELTE BTK-n}

A képzést gondozó ELTE BTK Könyvtár- és Információtudományi Intézete egyedülállóan teljes képzési kínálatot biztosít az országban az alapképzéstől a doktori fokozatszerzésig. ${ }^{27}$

Az oktatás a szakmai együttmüködő partnerek bevonásával történik, akik részt vesznek a szakmai gyakorlatok lebonyolításában, külsős oktatókat és bizottsági tagokat delegálnak, szakdolgozati témavezetőként dolgoznak, közös rendezvényeket bonyolítanak: Bács-Kiskun Megyei Katona József Könyvtár, Budapesti Corvinus Egyetem Egyetemi Könyvtár, Budapesti Müszaki Egyetem Országos Müszaki Információs Központ és Könyvtár, Csorba Győző Könyvtár, ELTE Egyetemi Könyvtári Szolgálat, Evangélikus Országos Gyüjtemény, Fővárosi Szabó Ervin Könyvtár, Infodok Kft., Központi Statisztikai Hivatal Könyvtár, Magyar Könyvtárosok Egyesülete, Magyar Olvasástársaság, Monguz Kft., Nemzeti Audiovizuális Archívum, Nemzeti Cirkuszmüvészeti Központ, Országgyülési Könyvtár, Országos Idegennyelvü Könyvtár és Zenei Gyűjtemény, Országos Széchényi Könyvtár, Ráday Könyvtár, Szellemi Tulajdon Nemzeti Hivatala, Színház- és Filmmüvészeti Egyetem Könyvtár, Kottatár és Médiatár.

Intézetünk ERASMUS partnerei biztosítják a rendszeres oktatói és hallgatói mobilitást: Åbo Akademi University, Turku; Alexander Technological Educational Institute of Thessaloniki; Babes-Bolyai Tudományegyetem, Kolozsvár; Hacettepe Üniversitesi, Ankara; Högskolan i Borås; Ionian University, Corfu; Johannes Gutenberg Universität, Mainz; Latvijas Universitāte, Riga; Oslo Metropolitan Uni-

MLS to the MLD: Integrating Design Thinking and Philosophy into Library and Information Science Education. $=$ Re-envisioning the MLS: Perspectives on the Future of Library and Information Science Education. Eds. Percell, Johnna -Sarin, Lindsay C. - Jaeger, Paul T. - Bertot, John Carlo (Advances in Librarianship, Vol. 44A). Bingley, Emerald. 2018. 210. p. https://doi.org/10.1108/ S0065-28302018000044A018

${ }^{27}$ A fejezetben közöltek hivatkozásokkal történő alátámasztásától terjedelmi okokból eltekintünk, az adatok és a fotók forrása jellemzően az ELTE BTK Könyvtár- és Információtudományi Intézetének honlapja: http://lis.elte.hu. 
versity; Sapienza Università di Roma; Sveučilište J.J. Strossmayera u Osijeku; Technische Hochschule Köln; Universidad Carlos III de Madrid; Universidad de León; Universidad de Salamanca; Universidade do Porto; Università degli Studi di Firenze; Universitatea de Vest, Temesvár; Université Sciences Humaines et Sociales, Lille; Uniwersytet Jagielloński w Krakowie.

Angol nyelvű (ERAMUS és Stipendium Hungaricum hallgatók számára ajánlott) kurzusainkat jól kiegészítik a szakmai közönség számára is nyilvános vendégelőadásaink.

Az oktatás mellett nemzetközileg jegyzett kutatási tevékenységünk elsősorban a Könyvtártudományi Doktori Program égisze alatt folyik: a Q1-es és Q2-es SJR-besorolású, impaktfaktoros, angol nyelvü közlemények; a legnagyobb hazai könyvtár- és információtudományi konferenciasorozat (Valóságos könyvtár könyvtári valóság, VKKV); aktív szerepvállalás a legjelentősebb szakmai világszervezetben, Barátné Hajdu Ágnes két cikluson keresztül a Könyvtáros Egyesületek és Szervezetek Nemzetközi Szövetsége (International Federation of Library Associations and Institutions - IFLA) igazgatótanácsi tagja első és egyedüli magyarként; két ciklusban a Bill and Melinda Gates Foundation Advisory Board tagja, a Nemzetközi Ismeretszervezési Társaság (International Society for Knowledge Organization - ISKO) Scientific Advisory Council, valamint a Universal Decimal Classification (UDC) Consortium Editorial Team és Executive Committee tagja ${ }^{28}$ Kiszl Péter a Webology és az International Journal of Digital Humanities (Springer) szerkesztőbizottsági tagja; további tudományos testületi tagságok, felkérések; CIII-HU-1407-01-1920-LISCE - Library and Information Science in Central Europe CEEPUS-hálózat vezetése stb.

Az egyes képzési szintek hálótervei, illetve tantárgyai kellő mozgásteret biztosítanak a mindig aktuális munkaadói elvárások beépítésére, a korszerü ismeretek elsajátítására. Az alapképzés alapozó elméleti ismeretei és szakmai törzsanyaga: Bevezetés a könyvtár- és információtudományba; Kutatásmódszertan; Közgyüjteményi ismeretek; Kommunikáció és informatika alapjai; Fenntarthatóság és könyvtár; Információelmélet, információs müveltség; Olvasásszociológia, -pedagógia, -pszichológia; Könyv- és könyvtártörténet; Sajtó- és könyvkereskedelemtörténet; Formai feltárás, dokumentumleírás; Osztályozási rendszerek, információkereső nyelvek, tartalmi feltárás; Könyvtártan; Gyüjtemény- és szolgáltatásmenedzsment; Menedzsment ismeretek; Tájékoztatás, információforrások; Adatbázisépítés; Integrált könyvtári rendszerek; Digitális

${ }^{28}$ Barátné Hajdu Ágnes nemzetközi szakmai szerepvállalásáról bővebben: Kiszl Péter: Könyvtárdiplomácia - tudomány- és szakmapolitika a nemzetközi könyvtári-információs szervezetekben. = Információközvetítés és közösségépítés - multifunkciós könyvtári hálózatok. Szerk. Kiszl Péter - Németh Katalin. Budapest, ELTE BTK Könyvtár- és Információtudományi Intézet. 2020. 9-30. p. https://doi.org/10.21862/infkoz.9 
gyüjtemények fejlesztése; Szakirodalmi adatbázisok; Webszerkesztés; Hálózati ismeretek; Hálózati kommunikáció; Projektmenedzsment; Szakmai gyakorlat.

Az egymást kiegészítő két BA-specializáció képviseli a hagyományos és a modern könyvtárosszerepre való komplementer orientáció lehetőségét. A könyvtörténeti specializáció tantárgyai: Művelődés- és könyvtártörténet; Nyomdászattörténet; Kiadótörténet; Paleográfiai és kodikológiai alapismeretek; Muzeális gyüjtemények számítógépesítése; Régi könyvek katalogizálása; Könyvkötés történet; Könyvművészeti törekvések; Latin nyelv; Kutatástámogatás. Az információ- és tudásmenedzsment specializáció tanegységei: Gazdasági, vállalkozói, jogi alapismeretek; Információ- és tudásmenedzsment; Marketing és pr; Üzleti kommunikáció; Üzleti információ; Gazdasági szakirodalmi információ; Kutatástámogatás; Tartalomkezelő rendszerek; Szerzői jog, információs etika; Üzleti levelezés, helyesírás; Dokumentumszerkesztés, tipográfia.

Az egyetemi könyvtárak munkaerö-utánpótlásának szempontjából főként a mesterképzésben végzett szakemberek dominálnak, így az MA-szint legutolsó, 2019-es felülvizsgálatakor erőteljesen figyelembe vettük e könyvtártípus igényeit. A huzamosabb elköteleződéssel járó és esetleg korlátozó beidegződéseket előidéző specializációkat megszüntettük, és a mindenkori hallgatói (és munkaerőpiaci) igényeknek megfelelö, félévről félévre változó, összesen 36 kredit értékben elvégzendö, kötelezően választható tantárgycsokrot kínálunk a szakmai törzstárgyakon túl. A mindig soron következő szemeszter intézetünk által összeállított kínálatából a hallgatók többségi döntése alapján alakul ki a tárgyak órarendje.

Az MA szakmai törzs tantárgyai: Társadalom és könyvtár; Művelődéstörténet; Könyvtár- és információtudomány a 21. században; Piacgazdaság és könyvtárügy az információs társadalomban; Könyvtári-információs menedzsment és marketing; Formai feltárás, metaadat-rendszerek; Osztályozás, tudásreprezentáció; Szakirodalmi tájékoztatás, tudásbázisok; Könyvtári adatbázisok, hálózati információs szolgáltatások; Társadalmi felelősségvállalás; Hagyományos dokumentumok, régi könyvek; Elektronikus dokumentumok, digitalizálás; Tartalomszolgáltatás és közösségi média; Tartalomszolgáltatás és multimédia; Angol szaknyelv; Szellemi tulajdon védelem; Tudománymetria; Szakmai gyakorlat.

Az MA specializációk helyett bevezetett, évfolyamonként személyre szabott szakmai modul választható tárgyai: Gazdasági ismeretek; Alkalmazott- és természettudományi tájékoztatás; Társadalom-, bölcsészettudományi és művészeti tájékoztatás; Minőségmenedzsment; Társadalmi egyletek és könyvtáraik; Az olvasás története; Irodalomterápia; Online közösségfejlesztés, e-learning; Kistelepülési könyvtári ellátás; Használóképzés; Az IFLA stratégiai irányai, nemzetközi trendek; Könyvtárépítészet; Könyvtáros kompetenciák, kulturális örökség; Konnektivizmus, szervezetfejlesztés; Digitális bölcsészet; Informá- 
ciótörténet; Információvizualizálás; Digitális gyűjtemények; Korszerü információmenedzsment- és marketing módszerek; Szervezeti információgazdálkodás, információs folyamatok; Üzleti információ és pénzügyi kultúra; Forrásszerzési, pályázatkészítési mühelymunka; Ügyvitel; Projektmunka.

Ahogy már említést tettünk róla, nemcsak a képzések kialakításában, hanem müködtetésükben is aktív együttmüködésben, közösen dolgozunk a könyvtáros szakmával, annak jeles intézményeivel, képviselőivel. Összefoglalva (és a konferencián vetített fényképekkel is dokumentálva) képzésünk föbb duális elemei:

- Alapszakon 300 óra, mesterszakon 150 óra szakmai gyakorlat teljesítése kötelező (a legnépszerübb partnereink sorrendben: ELTE Egyetemi Könyvtári Szolgálat (EKSZ), Országos Széchényi Könyvtár (OSZK), Fơvárosi Szabó Ervin Könyvtár (FSZEK), Infodok Kft., Országgyülési Könyvtár (OGYK), Budapesti Corvinus Egyetem Központi Könyvtár (BCE KK), Budapesti Müszaki Egyetem Országos Müszaki Információs Központ és Könyvtár (BME OMIKK), Központi Statisztikai Hivatal (KSH) Könyvtár, Magyar Nemzeti Múzeum (MNM) Könyvtára, Országos Idegennyelvü Könyvtár és Zenei Gyüjtemény (OIK), Semmelweis Egyetem Központi Könyvtár (SE KK), Magyar Tudományos Akadémia Könyvtár és Információs Központ (MTA KIK)). A tematika szerinti szakmai gyakorlatok teljes egészében a fogadóintézményekben, az ott dolgozó gyakorlatvezetők instrukciói alapján, felügyeletével és értékelésével zajlanak (3. ábra);

- A szakdolgozati (és esetenként a tudományos diákköri - TDK) témákat szakmai együttmüködő partnereink bevonásával, javaslatuk alapján határozzuk meg, évente szakdolgozati tájékoztató fórumot tartunk, majd számos esetben kettős (belső és külső) témavezetéssel folyik a munka (4. ábra);

- A doktori témák a nemzetközi trendeknek megfelelően alakulnak, a 2014-től felvettek kutatásai: mesterséges intelligencia és a könyvtárak; nemzeti könyvtárak funkciórendszere a digitális korban; a zöld könyvtári szemlélet, a környezettudatos, digitális megoldások és a fenntarthatóság vizsgálata és lehetséges modelljei; a BIBFRAME bibliográfiai keretrendszer alkalmazási lehetöségei a magyar könyvtári környezetben; az európai kulturális örökség digitális reprezentációja; egy középkori kézirat miniatúrájának keletkezésével kapcsolatos interdiszciplináris (egyiptológiai, ikonográfiai, kodikológiai, vallástudományi stb.) kutatások; a 21. századi közkönyvtár társadalmi kontextusa; az EU-s és a magyar szerzöi jogi aktusok, normaszövegek könyvtári vonatkozású összehasonlító elemzése; helyismereti gyüjtemények a 21. század digitális világában; az Open Access és a digitalizált dokumentumok online 
szolgáltatása; a Magyar Állami Földtani, Geofizikai és Bányászati Adattár története és gyüjteményének sajátosságai; fenntartható digitalizálás; a tárgyak internete és a könyvtár; a magyar nemzeti kulturális javak digitális megőrzésének tudományos, egzakt vizsgálata; a digitalizálás költségei; gamifikáció könyvtári környezetben. A közelmúltban sikerrel megvédett disszertációk: Bella Katalin: A Szépirodalmi Könyvkiadó története (1950-1956); Juhász Éva: Könyvtárgazda(g)ság: pénzügyi vonatkozású korszerü menedzsmenteljárások könyvtári alkalmazása; Lencsés Ákos: A statisztikai adatáramlás és adatszabályozás módszerei és lehetöségei a kezdetektöl napjainkig Magyarországon; Orbán Anna: Divéky József grafikus élete és munkássága, társadalmi és müvészi kapcsolatai a XX. század elsö felében Arthur Roessler részére irt levelei tükrében. A bírálóbizottságok elnökei az ELTE BTK neves professzorai voltak: Kulcsár Szabó Ernö, az MTA rendes tagja; Bollobás Enikö, az MTA levelező tagja; Erdődy Gábor, az MTA doktora; Manherz Károly, kandidátus.

- A Könyvtártudományi Doktori Program Részvétel a kutatóhely munkájában moduljából néhány, az ELTE BTK Könyvtár- és Információtudományi Intézete által kötött szakmai együttmüködési megállapodásokon nyugvó, aktív és naprakész hallgatói kutatói munkavégzést bizonyító példa:

- Országos Közegészségügyi Intézet - a Rockefeller Alapitvány által a világban alapított közegészségügyi központokban üzemelő gyüjteményekkel történő hálózatépítés előkészítése;

- OSZK - az OKR Könyvtárszakmai munkacsoportjában a könyvtári szabványosítási törekvések (RDA, MARC21, BIBFRAME) implementációjának támogatása;

- Magyar Cirkusz és Varieté Nonprofit Kft. (MACIVA) - Múlt, jelen, jövő - egy időben, egy helyen program keretében felhasználói igényfelmérések elvégzése a létesítendő cirkuszinformációs központtal kapcsolatosan, majd részvétel a Nemzeti Cirkuszmủvészeti Központ könyvtárfejlesztésében (Közép-európai Cirkuszművészeti Kutatóközpont és Adattár).

- Vendégelőadók (beleértve gyakorló könyvtáros oktatók) rendszeres foglalkoztatása, kurzusok a szakma hazai és nemzetközi neves képviselőivel (5. ábra), kihelyezett tanórák (6. ábra), záróvizsgákon és doktori szigorlati, munkahelyi vita, védési bizottságokban külső tagként történő felkérések. Külső óraadóink az elmúlt néhány félévböl: Amberg Eszter, Csorba Gyözö Könyvtár; Bándoli Katalin, Fövárosi Szabó Ervin Könyvtár; Bilicsi Erika, MTA Könyvtár és Információs Központ; Giczi András, BME Országos Müszaki Információs Központ és Könyvtár (majd OSZK); Hubay Miklós, Petöfi Irodalmi Múzeum; Kaposi Ildikó, 
Fövárosi Szabó Ervin Könyvtár; Legeza Dénes, Szellemi Tulajdon Nemzeti Hivatala; Mátyás Melinda, ELTE Egyetemi Könyvtár (Monguz Kft.); Nagy Andor, OSZK Könyvtári Intézet; Nagy Roland, ELTE Egyetemi Könyvtár; Ráczné Radó Rita, OSZK; Sárközi Andrea, Országos Idegennyelvü Könyvtár; Schubert András, MTA Könyvtár és Információs Központ; Simon András (Monguz Kft.); Sörény Edina, Nemzeti Közszolgálati Egyetem Egyetemi Központi Könyvtár és Levéltár (majd Emberi Eröforrások Minisztériuma); Szabó Panna, ELTE Egyetemi Könyvtár; Székelyné Török Tünde, ELTE Egyetemi Könyvtár; Szüts Gergely Etele, Forum Hungaricum - Magyar Nemzeti Digitális Archívum; Tóvári Judit, Eszterházy Károly Egyetem; Vass Anna Johanna, Magyar Müvészeti Akadémia Könyvtára; Winkler Beáta, Állatorvostudományi Egyetem Huẗ̈ra Ferenc Könyvtár, Levéltár és Múzeum.

- Külföldi vendégelőadók kutatásaiba is rendszeres bepillantást nyerhetünk. Közülük külön kiemelendő Ragnar A. Audunson (Oslo Metropolitan University), aki évröl évre tart kurzusokat doktori hallgatóinknak is. 2017-2018-ban vendégeink voltak még: Maria Micle (West University of Timisoara), Agata Walczak-Niewiadomska (University of Lodz); António Lucas Soares (University of Porto). A Digitális Bölcsészet Központtal együttmüködésben pedig a társtudományok részéről hallhattuk Henning Scholz (Europeana) (7. ábra), Mike Mertens (DARIAH) és Thorsten Ries (Ghent University), valamint Heinz Werner Kramski (Deutsches Literaturarchiv Marbach) kurzusait.

- Főállású, mellékfoglalkozású és tiszteletbeli (nyugdíjas) oktatóink ( $B a$ rátné Hajdu Ágnes, Bella Katalin, Bibor Máté, Boda Gáborné Köntös Nelli, Boros Tibor, Csík Tibor, Dippold Péter, Fodor János, Kerekes Pál, Kiszl Péter, Kosztyánné Mátrai Rita, Németh Katalin, Patkósné Tóth Zsuzsanna, Ráczné Radó Rita, Sebestyén György, Senkei-Kis Zoltán, Tószegi Zsuzsanna) mindegyike rendelkezik könyvtári- és tájékoztatási intézményben töltött gyakorlattal.

- Projektek (pl. Hazai György könyvtárának rendezése - 8. ábra, FSZEK hallgatói felmérés - 9. ábra, tartalomszolgáltatási mühely, Digitális Bölcsészet Központ, Voit Krisztina hagyatékának gondozása, Egyetemi Könyvtárért Alapitvány - 10. ábra).

- Rendezvények (pl. Nyitott Napok - 11. ábra; konferenciák - VKKV, Könyvtártörténet-irásunk a Rákosi-korszakról; könyvbemutatók; könyvtárbusz a Trefort Kertben; szakmai napok, mühelybeszélgetések, workshopok, kiállítások -12 . és 13 . ábra; szervezett könyvtárlátogatások a hallgatókkal-14. és 15. ábra). 
- Saját kiadványok, kiterjedt publikációs (nemzetközi tudományos, impaktfaktoros, de országos médiumokban ismeretterjesztő is) tevékenység, kapcsolat más diszciplínákkal.

- Folyamatosan megújuló infrastruktúra (16. ábra).

- Élénk hallgatói részvétel szakmai eseményeken (pl. MKE vándorgyülés, IFLA kongresszus, BOBCATSSS - 17. ábra).

A rendezvények közül külön is kiemeljük a Valóságos könyvtár - könyvtári valóság (VKKV) című tudományos konferenciasorozatunkat, ahol előadásokkal és kerekasztal-beszélgetésekkel mindenkor kiemelt szerepet kapnak szakmai életünk jeles (gyakorló) képviselö, könyvtári vezetők, továbbá oktatóink és doktoranduszaink prezentációi, melyek ugyancsak praktikumorientált megközelítést képviselnek (18. és 19. ábra). Különösen így volt ez a 2019 novemberi szimpóziumunkon, ${ }^{29}$ ahol a Szakmai együttmüködő partnereink reflexiói a képzés munkaerőpiaci hasznosulásáról címü panelben megszólalt:

- Berecz Ágnes gyüjteményigazgató, Dunamelléki Református Egyházkerület Ráday Gyüjteménye

- Fazokas Eszter osztályvezető, Országos Széchényi Könyvtár Könyvtári Intézet Könyvtártudományi Szakkönyvtár

- Fonyó Istvánné főszerkesztő, Budapesti Müszaki és Gazdaságtudományi Egyetem Országos Müszaki Információs Központ és Könyvtár, Tudományos és Müszaki Tájékoztatás

- Haszonné Kiss Katalin régióigazgató, Fövárosi Szabó Ervin Könyvtár

- Kálóczi Katalin főigazgató, ELTE Egyetemi Könyvtár és Levéltár

- Kóródy Judit információszolgáltató központ vezető, Infodok $\mathrm{Kft}$.

- Redl Károly igazgatóhelyettes, Országgyülési Könyvtár

- Papp Anna Mária föigazgató, Országos Idegennyelvü Könyvtár és Zenei Gyüjtemény

- Kis Szilárd csoportvezetö, MTVA Digitalizációs Mühely Kft. Nemzeti Audiovizuális Archívum.

Gondolataik hamarosan olvashatók lesznek tudományos mühelyünk által gondozott Valóságos könyvtár - könyvtári valóság. Könyvtár- és információtudományi tanulmányok címü sorozat 2020 -as kötetében. ${ }^{30}$ A konferenciát és a jubiláló képzést videóüzenetben Christine Mackenzie, az IFLA elnöke köszöntötte.

${ }^{29}$ Kiszl Péter - Boda Gáborné Köntös Nelli szerk.: Valóságos könyvtár - könyvtári valóság IV. Konferenciaprogram az elöadások tartalmi összefoglalóival. Budapest, ELTE BTK Könyvtárés Információtudományi Intézet. 2019. 47 p. http://hdl.handle.net/10831/44574

${ }^{30}$ VKKV konferenciáink eddig megjelent kötetei: Kiszl Péter - Boda Gáborné Köntös Nelli szerk.: Valóságos könyvtár - könyvtári valóság. Könyvtár- és információtudományi tanulmányok 2016. Budapest, ELTE BTK Könyvtár- és Információtudományi Intézet. 2017. https://edit.elte.hu/ 


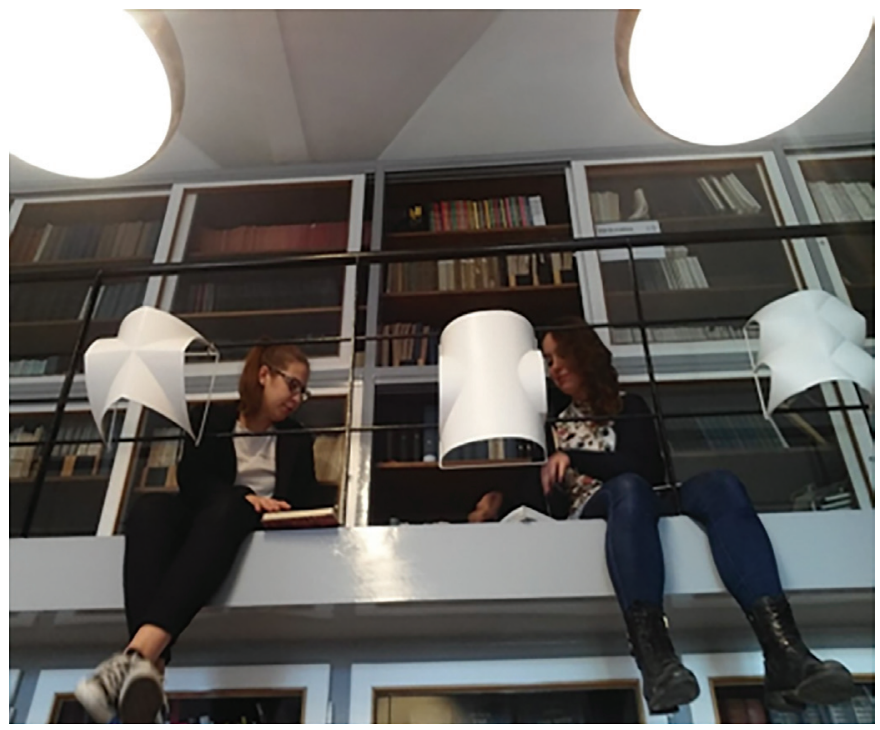

3. ábra. Szakmai gyakorlat a BME Építészmérnöki Kar Építészettörténeti és Müemléki Tanszékének könyvtárában (2017)

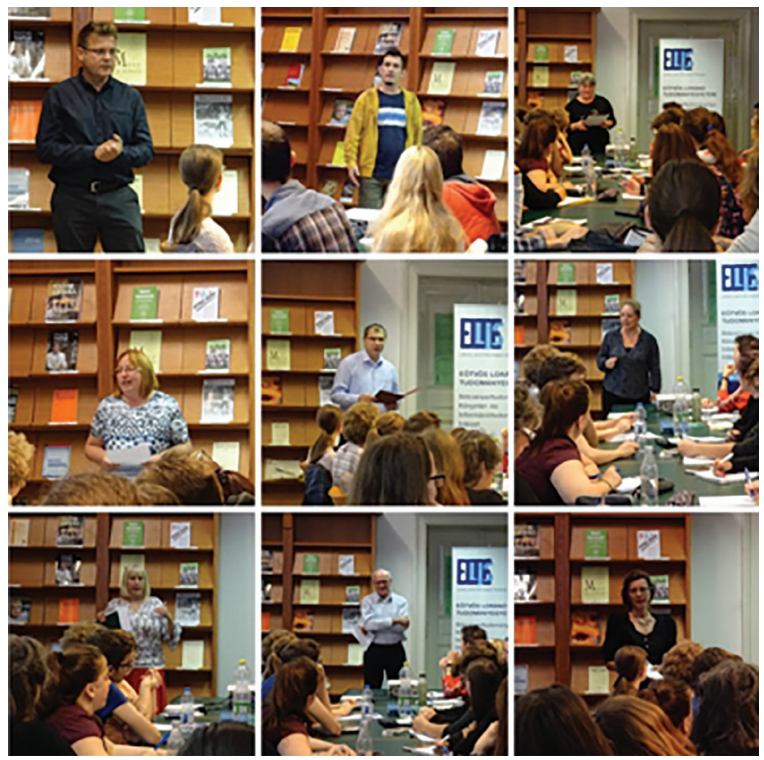

4. ábra. Szakdolgozati tájékoztató fórum szakmai együttmüködő partnerek részvételével (2019)

xmlui/handle/10831/34590; Kiszl Péter - Csík Tibor szerk.: Valóságos könyvtár - könyvtári valóság. Könyvtár- és információtudományi tanulmányok 2018. Budapest, ELTE BTK Könyvtár- és Információtudományi Intézet. 2018. https://doi.org/10.21862/vkkv2018 


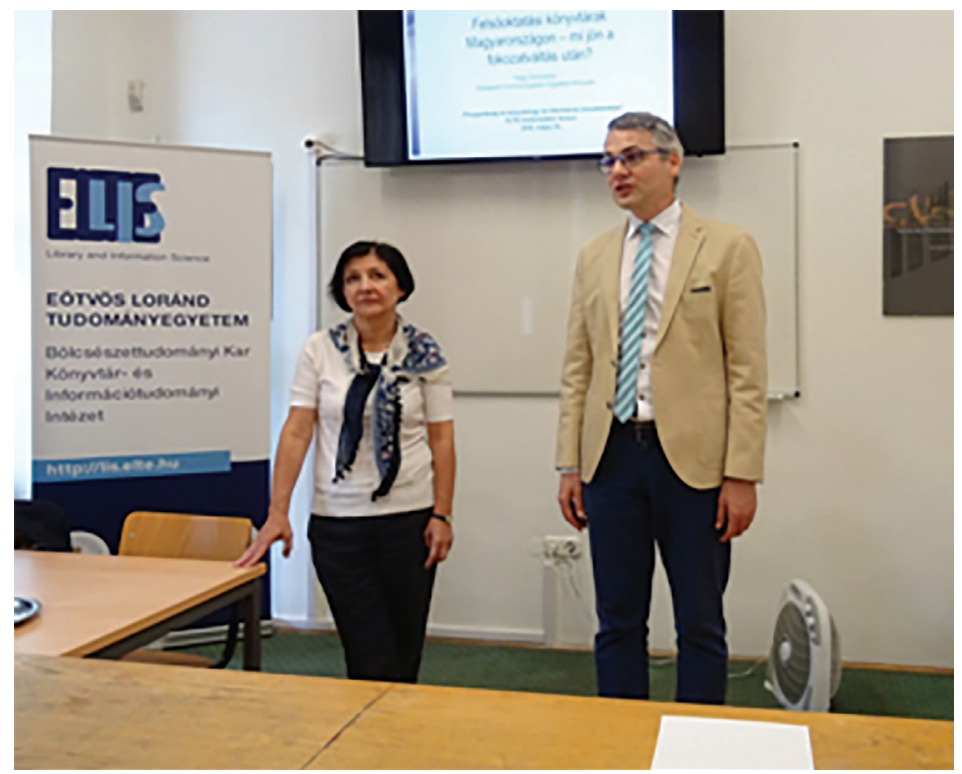

5. ábra. A Piacgazdaság és könyvtárügy az információs társadalomban mesterszakos kurzus keretében Nagy Zsuzsanna: Felsőoktatási könyvtárak Magyarországon - mi jön a fokozatváltás után? című vendégelőadása (2018)
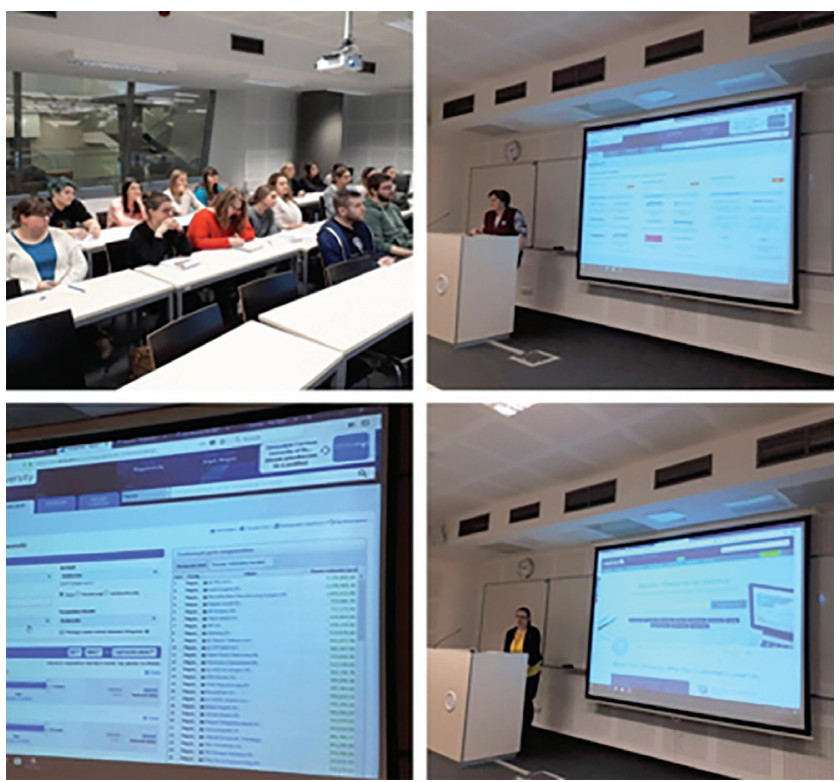

6. ábra. Kihelyezett tanóra (Üzleti információ) a Budapesti Corvinus Egyetem Központi Könyvtárában (2017) 


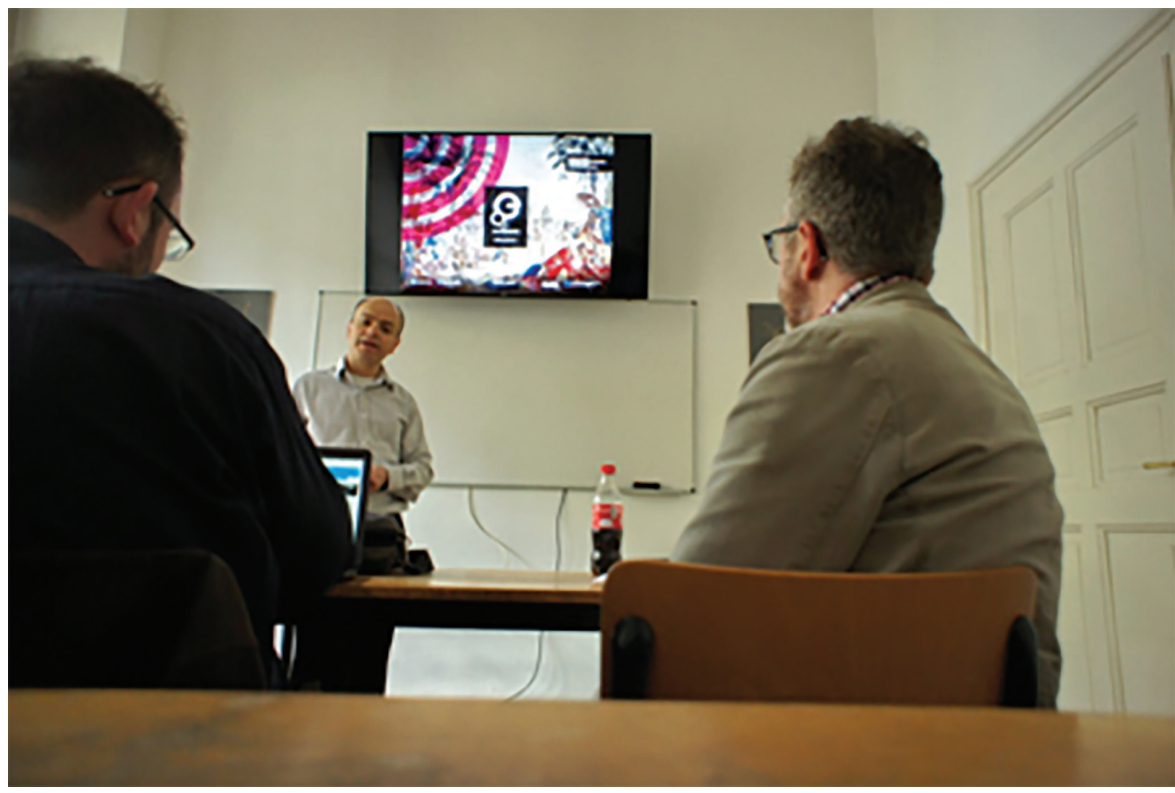

7. ábra. Henning Scholz (Europeana) vendégelőadása (2017)

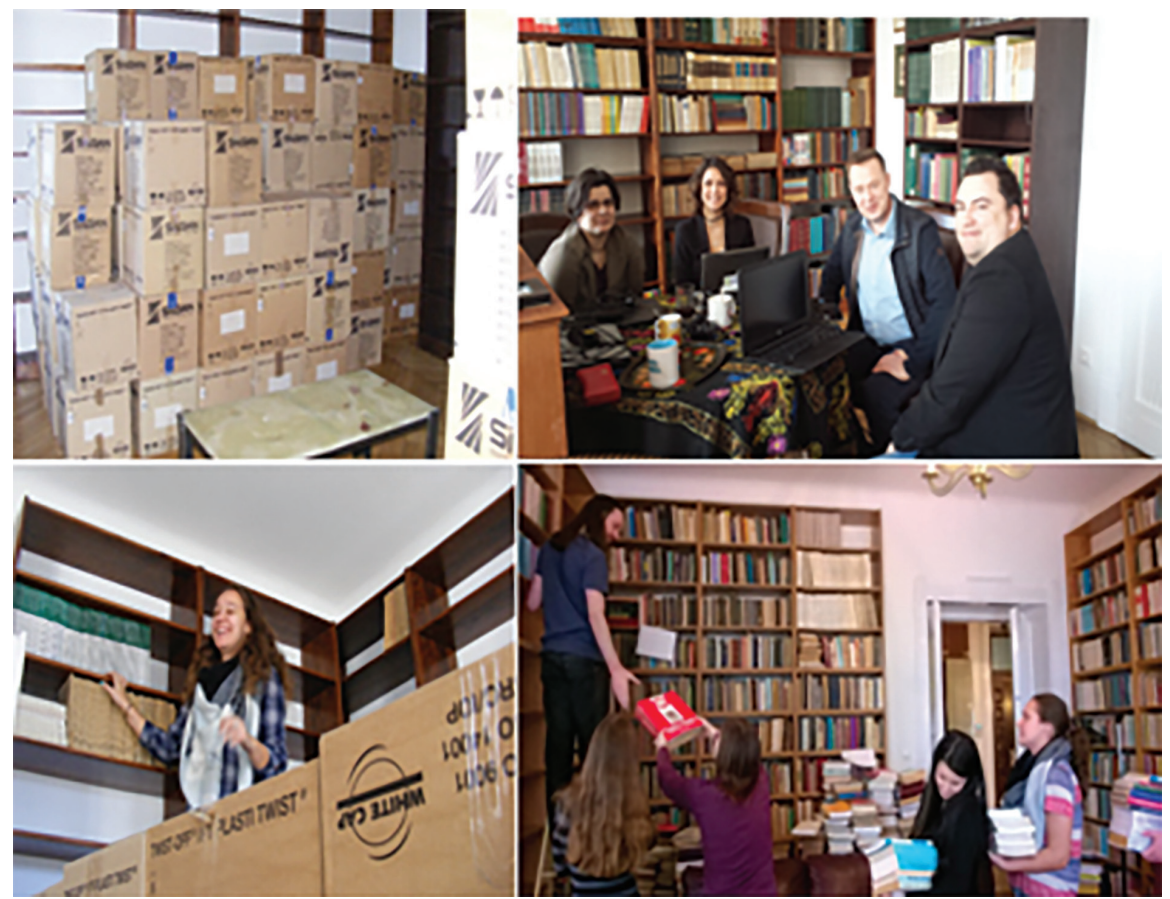

8. ábra. Hazai György könyvtárnak rendezése (2017) 

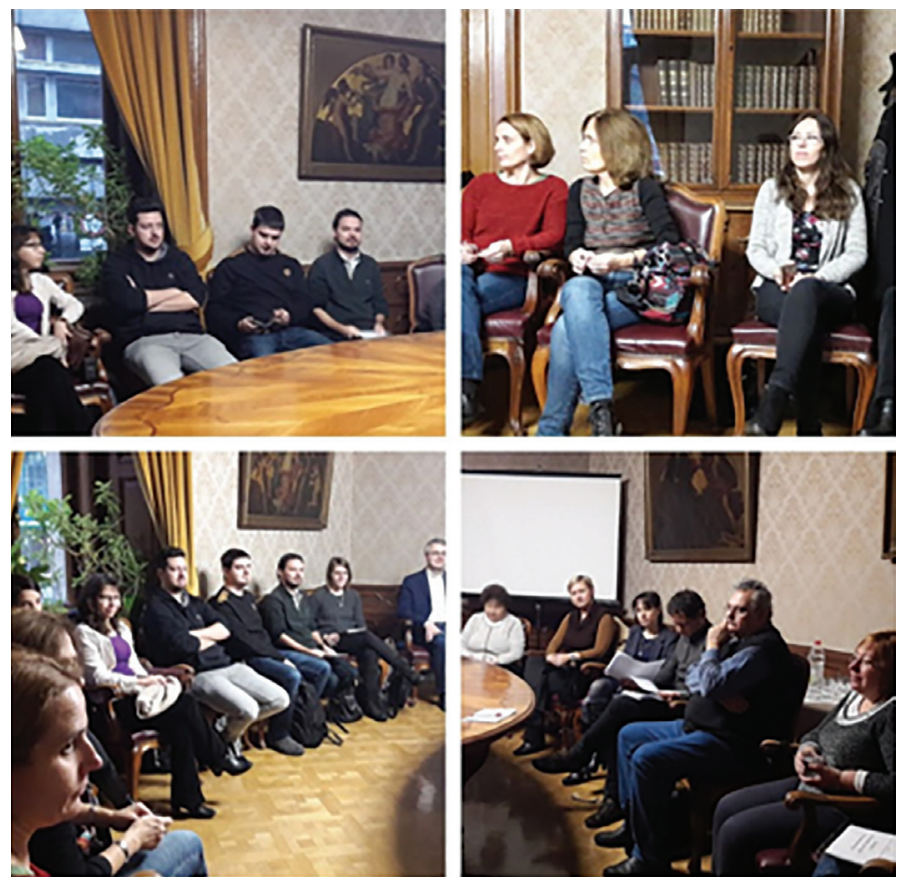

9. ábra. Hallgatói projektmegbeszélés a Fővárosi Szabó Ervin Könyvtárban (2017)

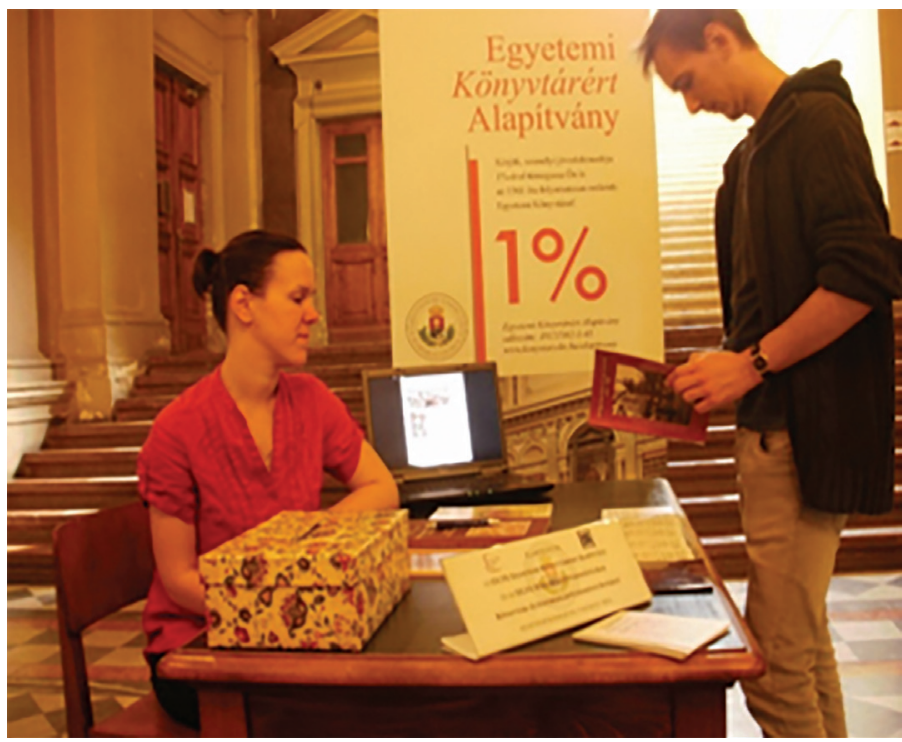

10. ábra. Az Egyetemi Könyvtárért Alapítvány hallgatók által müködtetett 1\%-os kampánystandja (2014) 

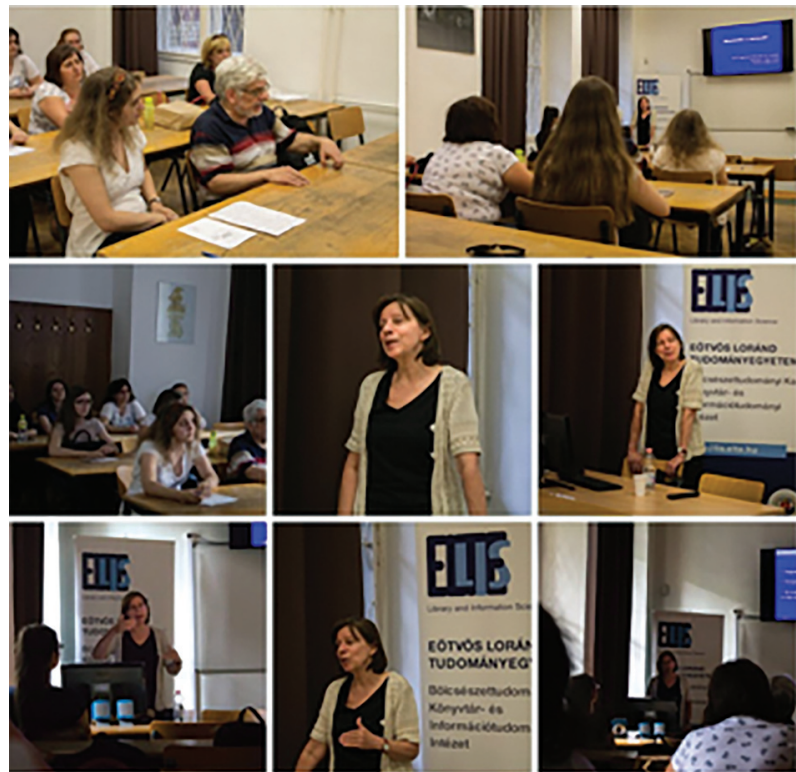

11. ábra. Székelyné Török Tünde vendégelőadása a Nyitott Napok sorozat új folyamának 20. alkalmán (2018)

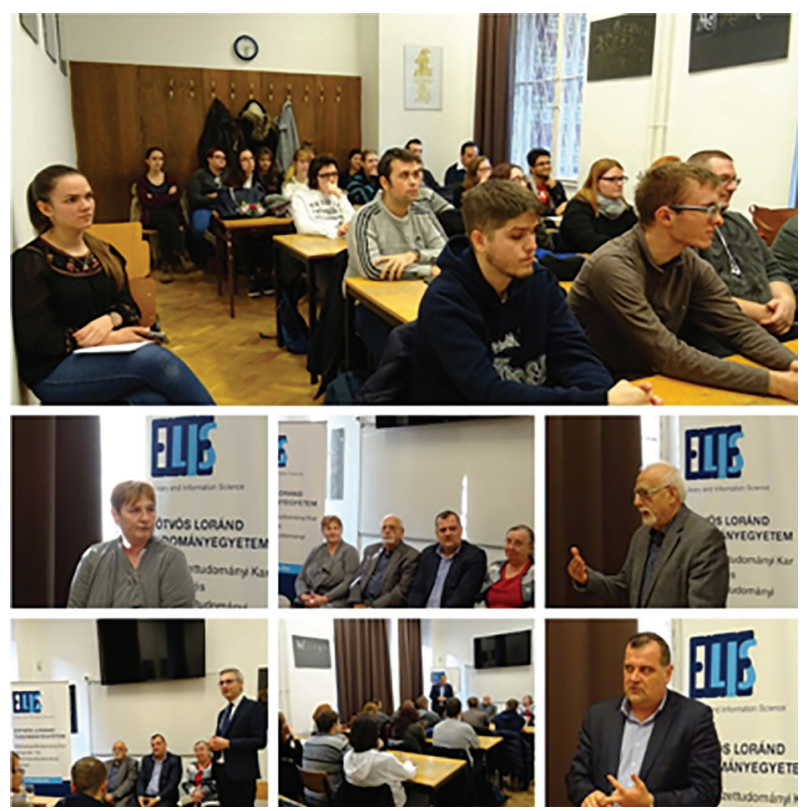

12. ábra. Mesterszakot népszerüsítő tájékoztató szakmai együttmüködő partnereink előadásaival (2018) 


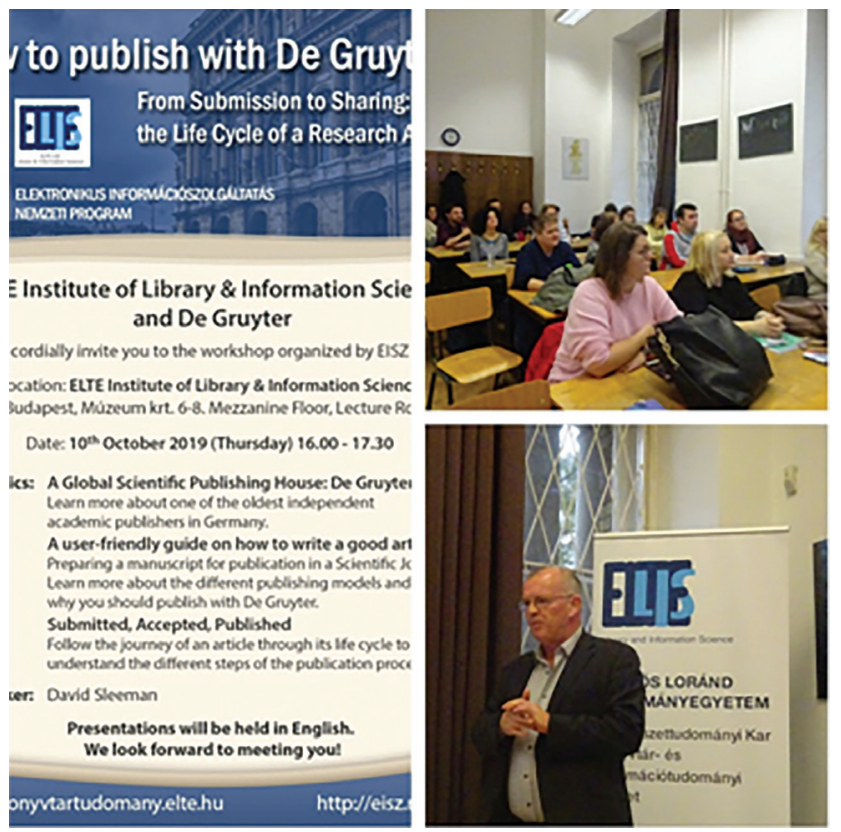

13. ábra. De Gruyter workshop az EISZ szervezésében (2019)
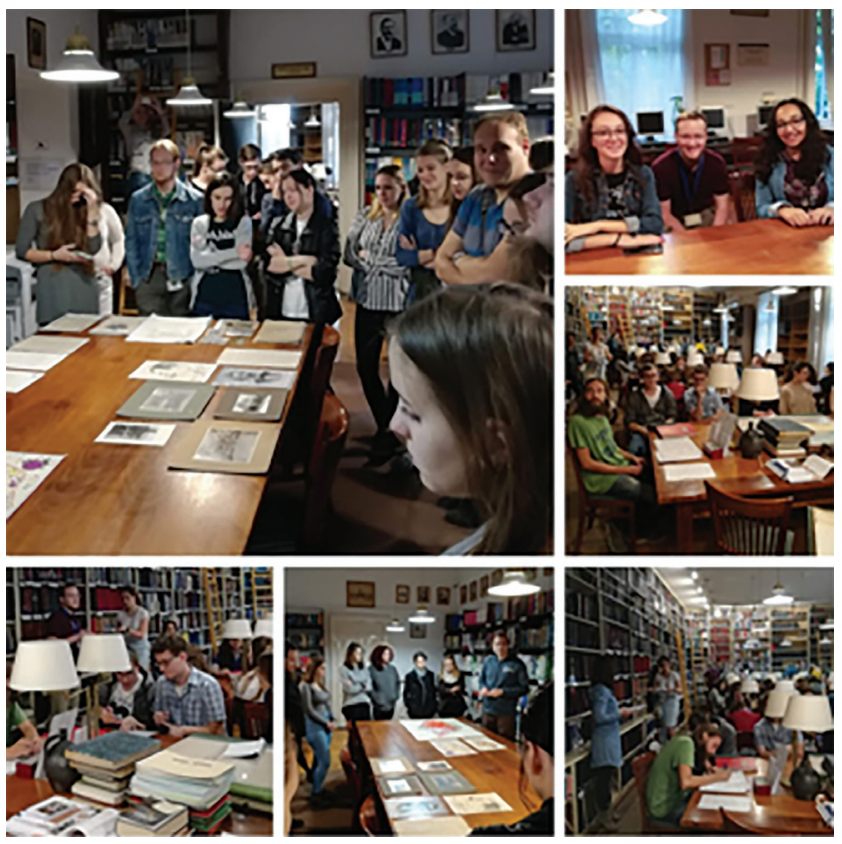

14. ábra. Szakmai látogatás a KSH Könyvtárban (2018) 


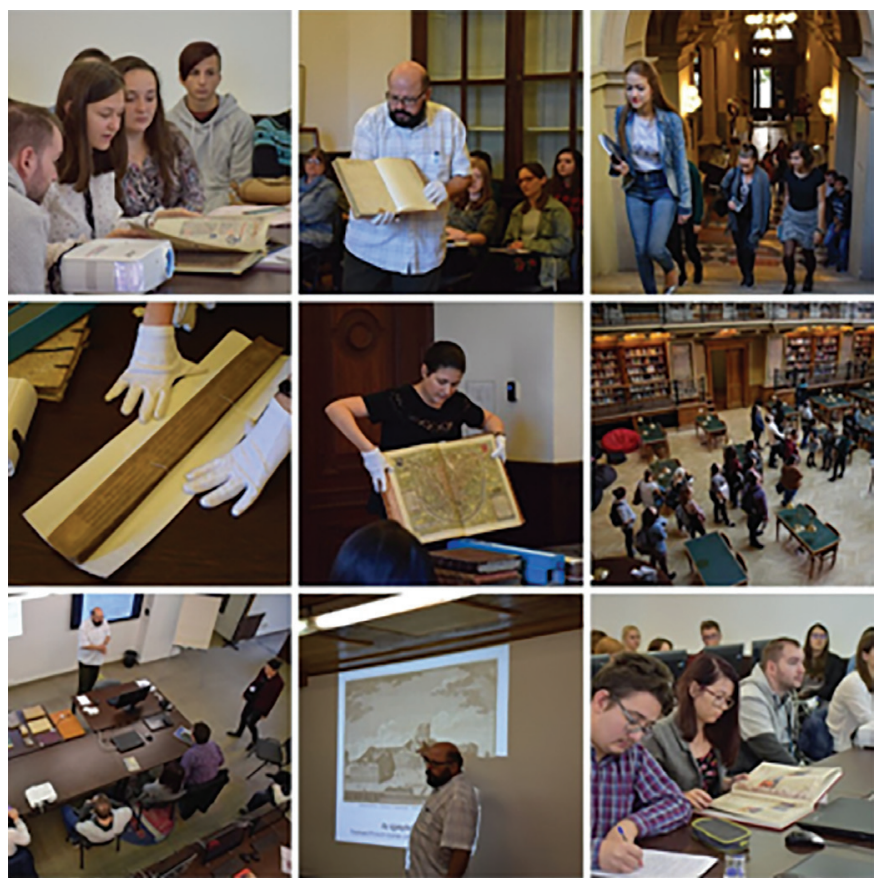

15. ábra. Szakmai látogatás az ELTE Egyetemi Könyvtárban (2020)

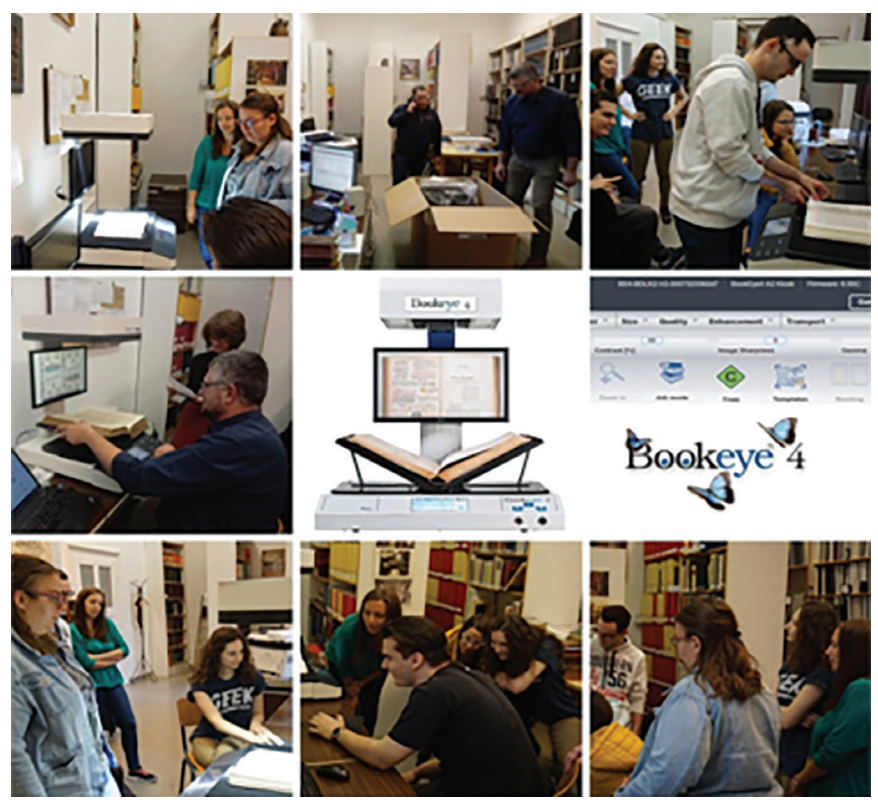

16. ábra. Bookeye könyvszkenner hallgatók általi birtokbavétele (2019) 


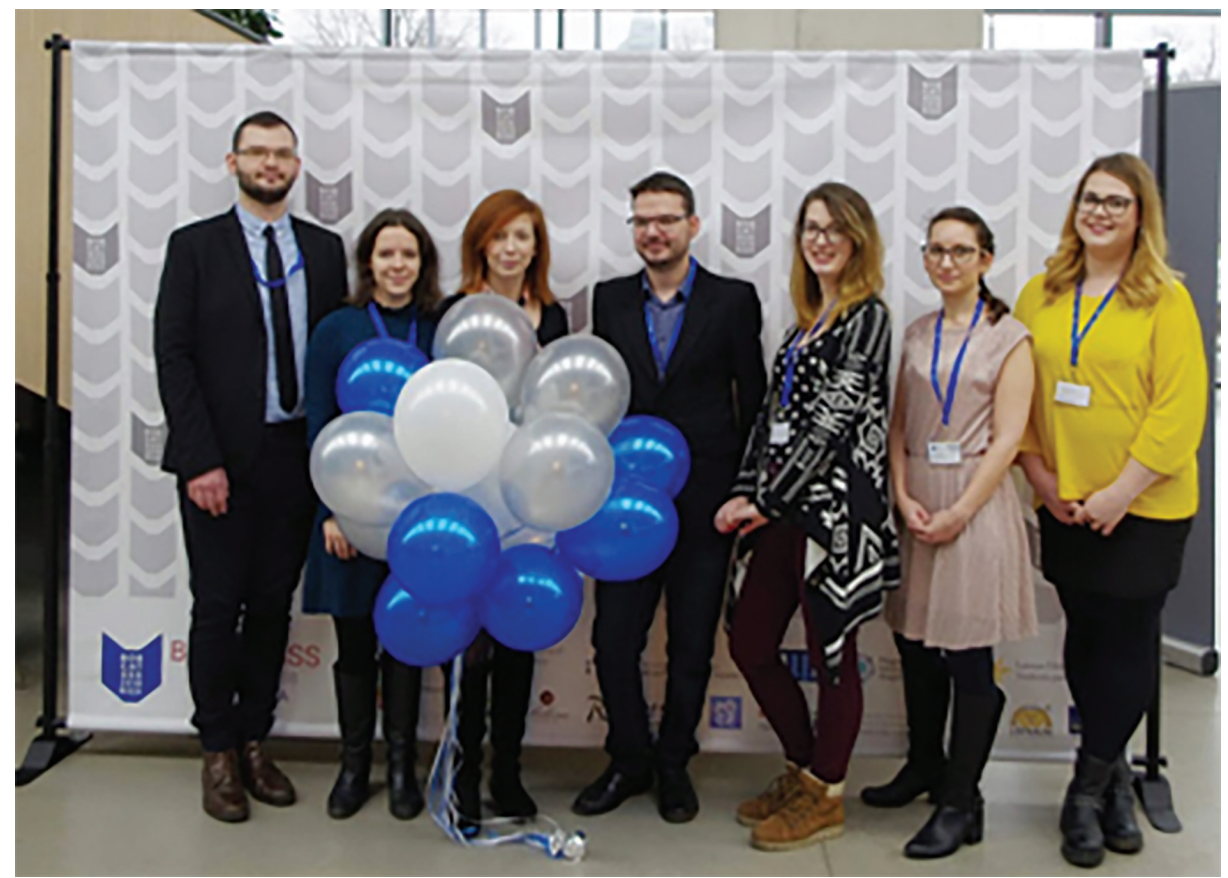

17. ábra. Hallgatóink a rigai BOBCATSSS konferencián (2018)
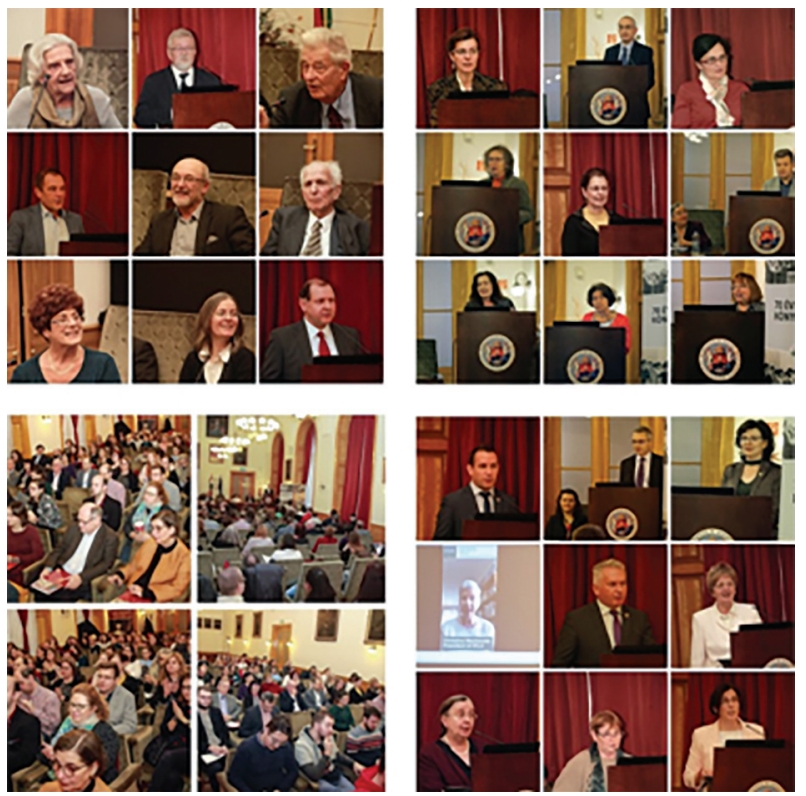

18. ábra. Jubileumi VKKV konferencia az ELTE BTK Kari Tanácstermében (2019) 


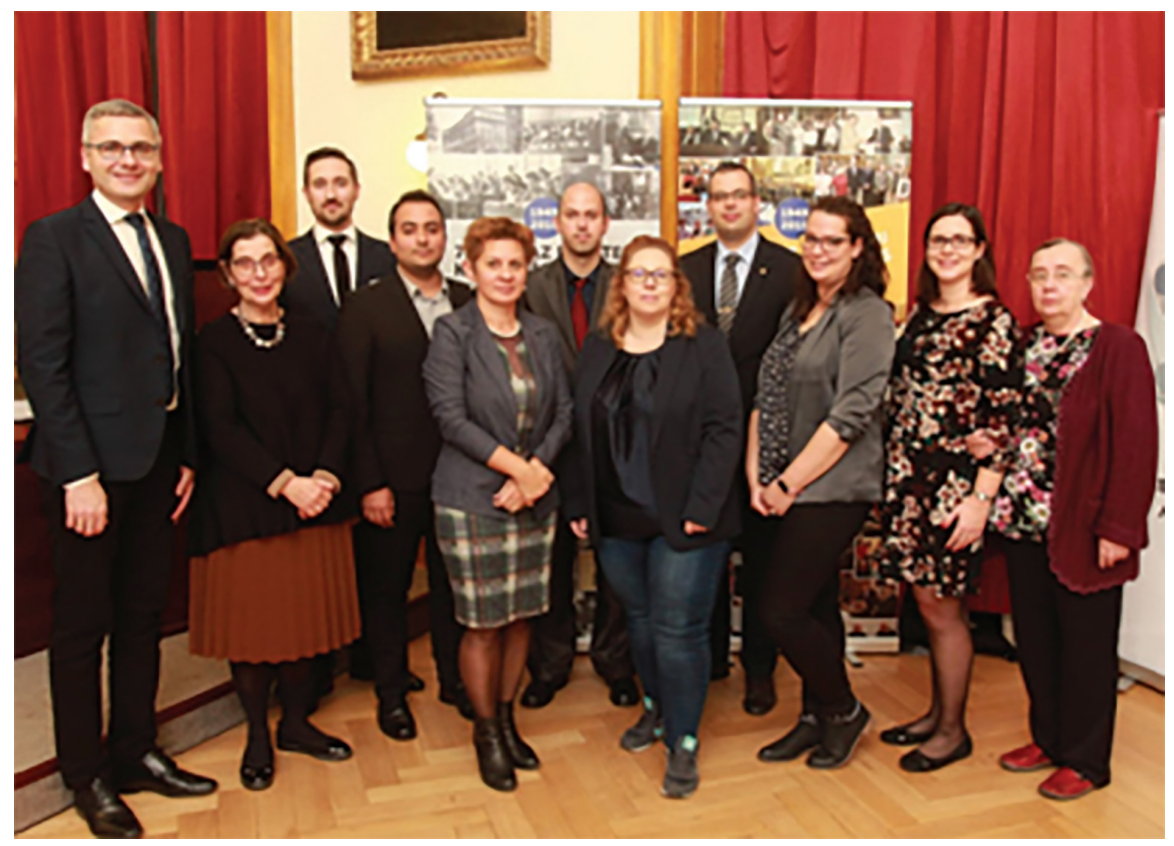

19. ábra. A jubileumi VKKV konferencián előadó doktoranduszok a képzés vezető oktatóival (2019)

Vélemények és tények

A következőkben a szaksajtóban és a szakmai rendezvényeken, fórumokon felmerült félreértésekre (nem teljességre törekvően, csupán válogatva) szeretnénk rendhagyó módon reflektálni - a megítélésünk szerint téves állítások, majd a félreértéseket tisztázó válaszok formájában.

Téves állítás: A képzési szintek tartalmi kialakításában nem vett részt a könyvtári gyakorlatot képviselö szakma.

Bemutattuk, hogy a képzés jelenlegi kereteinek felülvizsgálata, modernizálása a KKK-k fejlesztésével 2015 folyamán történt. A munkában - más szakokkal ellentétben - az érintett képzőhelyeken túl részt vettek a reprezentatív szakmai szervezetek (MKE, IKSZ, EKK), továbbá a Magyar Rektori Konferencia Könyvtári Főigazgatók Bizottsága, az EMMI ágazati képviselője és a hallgatók (HÖOK) delegáltja.

Téves állitás: A képzési rendszer nem elég rugalmas és nem veszi figyelembe az aktuális trendeket, jó gyakorlatokat.

A BA és MA képzés céljait és elsajátítandó kompetenciáit (tudás, képesség, attitűd, autonómia és felelősség) terjedelmi korlátok miatt nem ismertettük, azok 
a 18/2016. (VIII. 5.) EMMI rendelet a felsőoktatási szakképzések, az alap-és mesterképzések képzési és kimeneti követelményeiröl, valamint a tanári felkészités közös követelményeiröl és az egyes tanárszakok képzési és kimeneti követelményeiről szóló 8/2013. (I. 30.) EMMI rendelet módositásáról című jogszabályból kiolvashatók. Ismét hangsúlyozzuk, hogy nem szabályoztuk, ennélfogva intézményi hatáskörben hagytuk a specializációk indításának lehetöségét, továbbá a KKK intézményi hatáskörbe delegálja a tantárgyszintü kialakítást, kizárólag témaköröket és kreditsávokat szabályoz.

A hálótervek módosítása, a tantárgyak kialakítása az egyetemek döntésén múlik. A változtatások azonban időigényesek: a BA és MA képzési cikluson egyaránt keresztülvitt hálótervi módosítás több mint 5 év elmúltával éreztetheti csak hatását, ha nem vesszük figyelembe az előkészítő szakaszt (tanszéki, intézeti és kari tanácsi, majd szenátusi egyeztetések, illetve jóváhagyások). Körültekintő, megalapozott tantervfejlesztési döntésekre van tehát szükség, időtálló, kellően tág keretek közötti tantárgyelnevezésekkel, a kor kihívásainak megfelelő újabb és újabb ismereteknek inkább a tematikák folytonos (félévről félévre) elvégzett korszerüsítésében, a kutatói tapasztalatcserékben, publikációkban, tudományos diskurzusokban, továbbá a doktoranduszoknak és a szakma gyakorlati képviselőinek aktív oktatói szerepvállalásában kell megnyilvánulnia.

\section{Téves állitás: A felsőoktatási könyvtárak munkaerőpiaci igényeit sem minősé- gileg, sem mennyiségileg nem képes kielégíteni a hazai könyvtárosképzés.}

A kvalitatív (kompetenciafejlesztési) eredményeket, a képzés folyamatos fejlesztését, igazítását a munkaerőpiaci igényekhez - figyelembe véve nemzetközi beágyazottságát is - igazoltuk. Annyival egészíthetjük ki az eddigieket, hogy a sokoldalú felkészültségủ frissdiplomás könyvtáros szakemberek új, atipikusnak számító szerepekben is képesek müködni, sok a pályaelhagyó, ami nemcsak Magyarországon, hanem nemzetközi viszonylatban is tapasztalható. ${ }^{31} \mathrm{~A}$ végzettek valamennyi gazdasági szektorban keresetté, szívesen foglalkoztatottakká váltak, a képzés minőségileg tehát eredményesen müködik.

„...Az utóbbi években viszont érthető módon a munkavállalók a korábbinál is érzékenyebben reagálnak arra, hogy a könyvtárosi fizetések nem piacképesek. Aki tehát nem tudja, hogy mi akar lenni, vagy csak egyszerúen diplomát akar szerezni, az olyan szakokra jelentkezik, ahová a bejutáshoz (egyelőre még) nem kell emelt szintủ érettségi. Nyilvánvaló, hogy az informatikus könyvtáros képzés folyamatos korszerüsítésére szakterületünk gyors változásai nyomán szükség van, de semmiféle korszerủ oktatás nem tudja orvosolni az anyagi megbecsülés

${ }^{31}$ Fraser-Arnott, Melissa: The Value of the MLS or MLIS Degree: Transferable Skills Identified by LIS Graduates in Non-library roles. $=$ The Bottom Line, 29. vol. 2016. 3. no. 129 141. p. https://doi.org/10.1108/BL-03-2016-0015 
hiányát"32 - nyilatkozott Koltay Tibor 2019-ben a felsőfokú könyvtárosképzés helyzetéröl. Horváth Zita, felsőoktatásért felelős helyettes államtitkár 2019-ben megjelent, a Hagyományok és kihívások VII. konferencián 2018-ban elhangzott előadásában leszögezte: „A folyamatos infrastrukturális fejlesztés mellett legalább annyira lényeges a már könyvtárosként dolgozó kollégák megbecsülése, a könyvtárosi pálya vonzóvá tétele, hogy a szakemberek megtalálhassák a hivatásukat egy egyetemi könyvtárban” és ,... nem elegendő, ha elkötelezett kollégáink vannak az egyetemi könyvtárban, hanem az is szükséges, hogy lehetővé tegyük az ő képzésüket és a továbbképzésüket. E mögé nyilván forrást kell tenni." ${ }^{33}$

A kvantitatív részleteket ezen túlmenően a statisztikák világítják meg. A bölcsészet- és társadalomtudományok területén általánosnak tekinthető a hallgatói létszám csökkenése, amit szakmánk esetében tetéz az alulfizetettség, a közalkalmazotti státusz elvesztése, a rendkívül alacsony presztízs és érdekérvényesító képesség. A munkahelyek és a hallgatók által a 2 félév alatti teljesíthetőség miatt előnyben részesített segédkönyvtáros OKJ (és némileg a könyvtári szakember pedagógusoknak, család- és gyermekvédelmi szakembereknek szóló szakirányú továbbképzés) is rontja a jelentkezési hajlandóságot: „A Bizottság egyúttal felhívja a jogalkotók figyelmét olyan anomáliákra, amelyek a felsőoktatási szférán kívüli, ám annak működését közvetetten mégis érintő jogalkotás eredményez. Ilyen pl. a közalkalmazottak jogállásáról szóló 1992. évi XXXIII. törvény végrehajtásáról a művészeti, a közmüvelődési és a közgyüjteményi területen foglalkoztatott közalkalmazottak jogviszonyával összefüggő egyes kérdések rendezésére született 150/1992. (XI. 20.) Korm. rendelet 6/B. §-a, ami OKJ szerinti segédkönyvtárosi szakképesítéssel is lehetővé teszi könyvtárvezetői beosztások betöltését nem szakirányú felsőfokú végzettséggel és szakképesítéssel rendelkező személyek számára. A bizottság véleménye szerint az ilyen, a felsőoktatás területén kívül eső jogalkotás leértékeli a felsőoktatásban szerezhető szakmai végzettségeket és szakképesítéseket, amitől a szakmai követelmények biztosítása érdekében tartózkodni kell” - részlet a Bologna-revízió kapcsán a Magyar Rektori Konferencia Társadalomtudományi Bizottságának (MRK TTB) 2019. november 4-én megfogalmazott javaslatából.

A könyvtár- és információtudományi képzések hallgatói létszámának csökkenése nem meglepő, ilyen körülmények között a munka mellett végezhető levelező tagozatos tanulmányok fenntartása létkérdés. Elsősorban az „alulfizetettsége" (indokolását 1. a következő állításnál) miatt országos szinten jelentős

${ }^{32}$ A gyenge szakmai érdekérvényesítés a könyvtárosok számát is megtépázhatta. = KIT Hírlevél. 2019. március 17. http://www.kithirlevel.hu/index.php?kh=a_gyenge_szakmai_ erdekervenyesites_a_konyvtarosok_szamat_is_megtepazhatta

${ }^{33}$ Horváth Zita: A felsőoktatás fejlesztésének irányvonalai. = Hagyományok és kihívások VII. Országos Könyvtárszakmai Nap, 2018. Szerk. Szabó Panna - Székelyné Török Tünde. Budapest, ELTE Egyetemi Könyvtár és Levéltár. 2019. 14. p. https://doi.org/10.21862/HagyKihiv_2018.11 
létszámcsökkenést szenvedett mesterképzés megerősítésén segíthetnek az egyetemi könyvtárak vezetői: támogatják-e dolgozóik részidős tanulmányait, bevezetnek-e ösztöndíjprogramokat, megkövetelik-e az utánuk következő generációtól a szakirányú mestervégzettséget stb. Szükség van tehát a képzés szakma általi népszerüsítésére, a közoktatásban tanulók könyvtár- és könyvtárosképének javítására, a könyvtári dolgozók „beiskolázására” - egyszóval a széles körü összefogásra, ami megfordíthatja a szak iránt érdeklődők jelentkezési hajlandóságának csökkenését. A végzettek jelentős részének piaci szektorban történő elhelyezkedése aláhúzza a képzés jól konvertálhatóságát, a szakmai presztízs, az anyagi és erkölcsi megbecsülés hiányát, ami döntően befolyásolja a jelentkezéseket. A BA és az MA szakokra felvettek létszámának 2006 és 2020 közti alakulása a 20. és a 21. ábráról olvasható le. A végzettekröl sajnos nem rendelkezünk teljes körü országos adatokkal, azonban kiemeljük, hogy már a felvettek között is tapasztalható, hogy be sem iratkoznak (a 2019/2020-as tanévben az ELTE BTK-n nappali és levelezö tagozaton, informatikus könyvtáros alapszakon 14,5\%, míg könyvtártudomány mesterszakon $6 \%$ meg sem kezdte a tanulmányait), majd később különböző okokból - például munkavállalás, külföldi tanulmányok, tanulási nehézségek, nem az elképzelésnek megfelelő szakválasztás, szociális vagy egészségügyi problémák - ugyancsak többen elhagyják vagy nem fejezik be a képzést jellemzően az alapszakon, a mesterszakon már elenyésző számban. A 2020 előttiek diplomaszerzési statisztikáit az idei évben nyelvvizsga nélkül tömegesen megszerzett oklevelek nagyban javítani fogják.

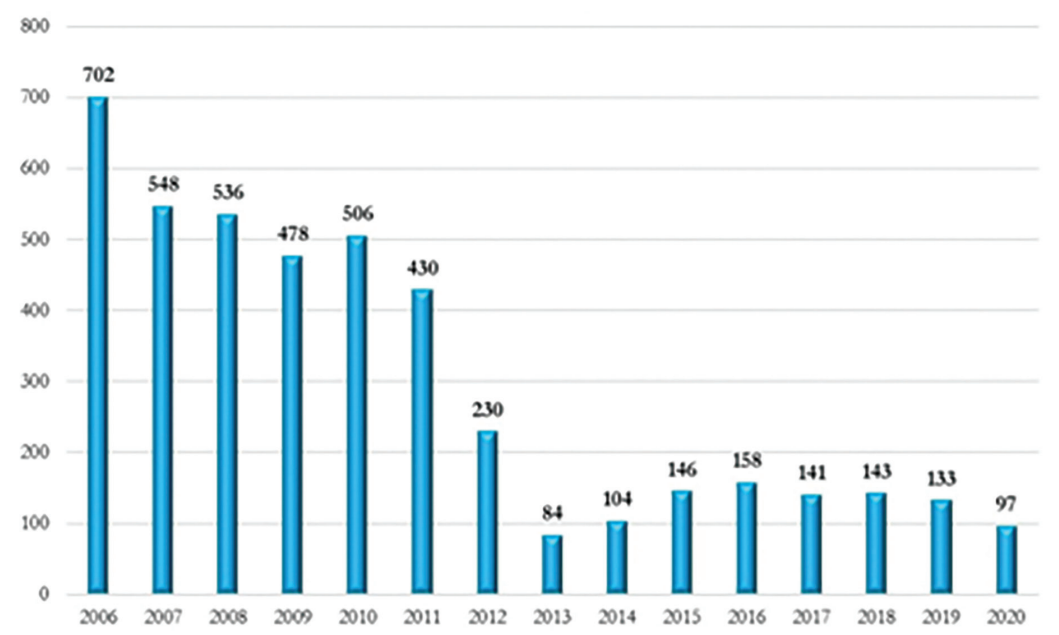

20. ábra. Informatikus könyvtáros alapszak valamennyi tagozatára (nappali, levelező, távoktatás és diplomás levelező) felvett hallgatók száma 2006-2020 között (A felvi.hu adatai alapján készítette: Németh Katalin) 


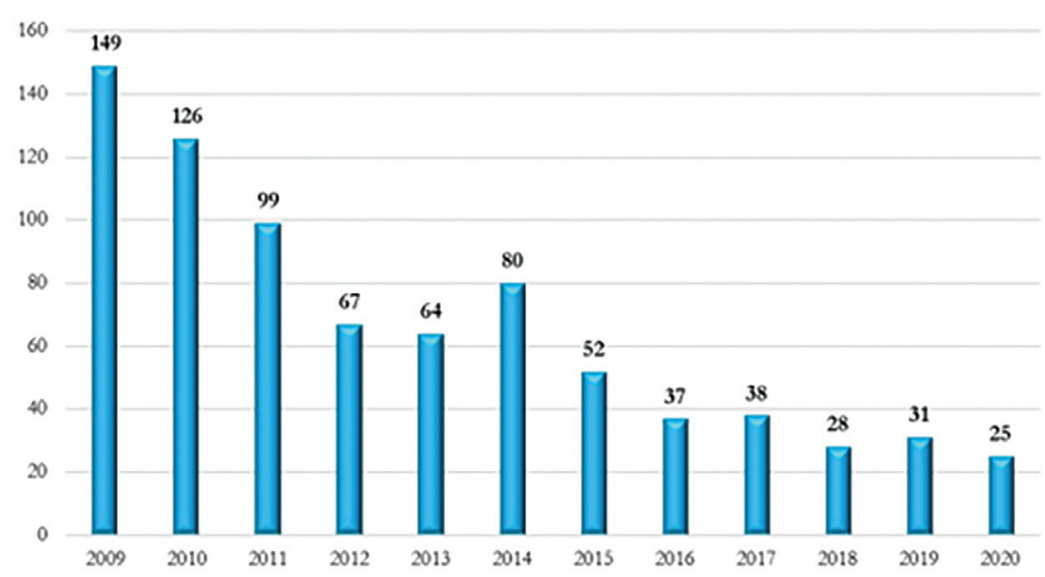

21. ábra. Könyvtártudomány mesterszak valamennyi tagozatára (nappali és levelezö) felvett hallgatók száma 2009-2020 között (A felvi.hu adatai alapján készítette: Németh Katalin)

A 2011. évi CCIV. törvény a nemzeti felsőoktatásról 2020. július 31-től hatályos módosítása kedvező helyzetet teremt a hallgatók számára, hiszen a mesterképzés után, két államilag támogatott félévben az informatikus könyvtáros MA diploma mellé könyvtárostanár végzettséget is szerezhetnek: 39 . § (4a) „A hallgató és a felsőoktatási intézmény további hallgatói jogviszonyt létesíthet a központi felvételi eljáráson kívül is mesterképzési szakkal párhuzamos képzésben felvett tanárszakra."

Téves állitús: A képzés sokszor nem a könyvtári szektorban történő munkavállalásra készít fel.

A képzés elsődleges célja Magyarország legnagyobb kulturális intézményrendszere, a könyvtári hálózat számára a szakemberek biztosítása. Itt is ki kell emelni azonban, hogy a képzőhelyek által nem befolyásolható okokból sok a pályaelhagyó a versenyszféra irányába (alapszak után a hallgatók kb. fele elhagyja a szakmát, a mesterszakot követően ez a szám jóval csekélyebb, 1/3 alatti) - nemzetgazdasági szinten a képzés viszont jól hasznosul, az Oktatási Hivatal (OH) Diplomás Pályakövetö Rendszer Adminisztrativ Adatbázisok Egyesitése (DPR AAE) szerint igen alacsony a végzettek között az álláskeresők aránya (2017-ben BA: 7\%, MA: 4\%), a korábbi (túlkínálati) helyzettel ellentétben a könyvtárakban nincs szakmai, elsősorban mesterszakot végzett utánpótlás, a diplomások egyre inkább könyvtárakon kívül helyezkednek el, könyvtári túlkereslet állt elö. A 2015/2016-os tanévben végzett alapszakos hallgatóink 20,69\%-a, míg a mesterszakosaink 39,47\%-a már dolgozott a képzés utolsó hónapjában, az átlagos 
elhelyezkedési idő 3, illetve 1,95 hónap volt. Ma ezek a százalékértékek jóval magasabbak, a hónapok pedig alacsonyabbak.

Az ezredforduló utáni évtizedben jelentős volt a munkaerőpiaci túlkínálat, valamennyi végzettünk számára a könyvtári hálózat nem tudott elhelyezkedési lehetőséget biztosítani, így nyitnunk kellett más irányokba, például a gazdasági, vállalkozói, jogi ismeretkörök megerősítésével a közigazgatásba vagy a vállalkozói szférába történő elhelyezkedés elősegítésére. Mára a helyzet gyökeresen megváltozott, sőt megfordult, könyvtári túlkereslet állt elö, nem jelentkezik elegendő frissdiplomás a könyvtáros állásokra, s oktatóként tapasztaljuk, hogy a hallgatók jelentős része (közel, de sokszor több mint fele) pályaelhagyó lesz, sajnos már nem könyvtárakban képzeli el a jövőjét. A pénzügyi vonatkozású kompetenciafejlesztésre azonban továbbra is fokozott elvárás mutatkozik, mind a hallgatók, mind a leendő könyvtári munkaadók részéről. ${ }^{34}$

A teljes képhez hozzátartozik a BA és az MA végzettek bruttó bére közti minimális különbség is, ami minden bizonnyal negatívan befolyásolja a BA-sok további (MA-s) tanulmányi hajlandóságát. A DPR AAE szerint 2017 decemberében a $232.390 \mathrm{Ft}(\mathrm{BA})$ mellett 245.177 Ft (MA) áll a köz- és a versenyszféra kereseteit is beleértve, eközben a KSH által közzétett bruttó havi átlagbér $327.700 \mathrm{Ft}$ volt. Így nem alaptalanok, ugyanakkor nem használnak a felsőfokú könyvtárosképzésnek az országos sajtóból például a Még pedikürözni is jobban megéri, mint könyvtárosnak lenni címü ${ }^{35}$ és a hozzá hasonló célzatú összeállítások. Inkább a könyvtárak és a könyvtáros hivatás 21 . századi szerepét reálisan bemutató, az átlagpolgárokat a multifunkciós könyvtári intézmények és a bennük dolgozók valódi tevékenységét, társadalmi hasznosságát és nélkülözhetetlenségét propagáló médiamegjelenések szolgálják az érdekeinket. Béremelés és versenyképesség-javulás a kulturális szektorban ${ }^{36}$ - a képzőhelyek is vára-

${ }^{34}$ Kiszl Péter: Pénzügyi kultúra, vállalkozásfejlesztés, képzés: a könyvtár mint a gazdasági fejlődés egyik záloga. = Valóságos könyvtár - könyvtári valóság: Könyvtár- és információtudományi tanulmányok. 2018. Szerk. Kiszl Péter - Csík Tibor. Budapest, ELTE BTK Könyvtár- és Információtudományi Intézet. 2018. 91-101. p. https://doi.org/10.21862/vkkv2018.91; „Négyes osztályzatot sem ért el a szakma pénzügyi jártasságból, marketing ismeretekből, vezetési ismeretekből és idegen nyelvekböl.” Megállapítja: Tóth Máté: A hazai felnőtt lakosság olvasási és könyvtárhasználati szokásai 2019-ben. Múzeumi és könyvtári fejlesztések mindenkinek. EFOP-3.3.3VEKOP/16-2016-00001. Az én könyvtáram. Budapest, Fővárosi Szabó Ervin Könyvtár. 2020. 44. p. http://www.azenkonyvtaram.hu/documents/11543/49234/Toth_Mate_Felnott_olvasas konyvtarhasznalat.pdf/07ba9b52-f9a3-40b4-84bf-6dbff50d218f

${ }^{35}$ Prókai Eszter: Még pedikürözni is jobban megéri, mint könyvtárosnak lenni. = Index. 2018. március 21. https://index.hu/belfold/2018/03/21/meg_pedikurozni_is_jobban_megeri_mint_ konyvtarosnak_lenni

${ }^{36}$ Béremelés és versenyképesség-javulás a kulturális szektorban. 2020. április 13.: https:// www.kormany.hu/hu/emberi-eroforrasok-miniszteriuma/kulturaert-felelos-allamtitkarsag/hirek/ beremeles-es-versenykepesseg-javulas-a-kulturalis-szektorban 
kozással tekintenek a könyvtárosok közalkalmazotti státuszának megszünésével egyidejüleg ígért bérfejlesztés, az anyagi megbecsülés, ezáltal a minőségi munkaerö-utánpótlás, a felsőfokú képzés hallgatói létszámának emelkedése elé.

Téves állitús: A képzésben nem vehetnek/vesznek részt gyakorló könyvtárosok. Ahogy azt kifejtettük, a szakindítás feltételeit a MAB követelményrendszere szabályozza. ${ }^{37}$ Magasabb szintủ képzésről lévén szó, szigorúbb elvárások érvényesülnek az oktatókkal szemben, mint a tanfolyami (OKJ és továbbképzés) formáknál. A MAB mesterképzésre vonatkozó szakindítási feltétele például, hogy a törzsanyag tantárgyainak (és az elméleti ismeretköröknek) felelősei tudományos fokozattal rendelkező oktatók, kutatók vagy más munkakörben foglalkoztatott szakemberek legyenek, és a törzstárgy-felelősök legalább 2/3-a az egyetemmel teljes- vagy részmunkaidős közalkalmazotti jogviszonyban álljon, továbbá a képzés „törzsoktatóinak” legalább 75\%-a, az intézményben folytatott gyakorlati foglalkozások vezetőinek legalább 50\%-a az intézmény foglalkoztatott oktatója legyen. A képzést támogatják ezen előírások, hiszen például az egyetemeken dolgozó, PhD-fokozattal rendelkező könyvtárosok is felkérhetők akár elméleti törzstárgyak tantárgyfelelőseinek (a MAB definíciója szerint a tantárgyfelelős: „a tantárgy oktatásának szervezéséért, fejlesztéséért felelös oktató”) és/vagy oktatónak. Nem törzsanyag és nem elméleti ismeret átadása, jellemzően szemináriumok és gyakorlatok esetében pedig nagy tapasztalattal bíró könyvtárosok, doktoranduszok PhD nélkül is tarthatnak foglalkozásokat.

Az ELTE BTK-n a 2019/2020. tanévben az összes képzési szint tanrendi kurzusainak hozzávetőlegesen 15\%-át külsős, gyakorló könyvtáros tartotta vendégoktatóként, megbízási szerződéssel, nem beszélve arról, hogy ezen felül az alapképzésben az óraszámok kb. 20\%-a, a mesterképzésben pedig kb. 15\%-a külső szakmai gyakorlat (MAB definíció: „speciális tantervi egység”), amit teljes egészében a könyvtárak, információszolgáltató intézmények szerveznek, vezetnek és értékelnek. A gyakorló könyvtárosok felsőfokú képzésben történő oktatói részvétele tehát eléri, sőt, alapképzésben meg is haladja az 1/3-os arányszámot, a szakma igen nagy súllyal részt vesz a jövő könyvtárosainak kompetenciafejlesztésében.

\section{Téves állitás: A szakelnevezések nem megfelelöek.}

Az informatikus könyvtáros BA szakelnevezés és végzettség a szóba jöhető alternatívák közül beváltnak tekinthető, az MA azonban javítható: könyvtártudomány helyett könyvtár- és információtudomány MA lenne kívánatos, illetve

${ }^{37}$ A MAB akkreditációs elvárásai, szakmai bírálati szempontjai (SzBSz) alapképzési szak/ szakirány indításának véleményezésében. Hatályos: 2017. január 1-től: http://old.mab.hu/web/tir/ doc/szbsz_bs3.pdf; A MAB akkreditációs elvárásai, szakmai bírálati szempontjai (SzBSz) (osztott és osztatlan) mesterképzési szak / szakirány, tanárszak indításának véleményezésében. Hatályos: 2017. január 1-től: http://old.mab.hu/web/tir/doc/szbsz_ms3.pdf 
a végzettségek elnevezésében mindenütt a nemzetközi normáknak megfelelő angol terminológia bevezetése, azaz a Library and Information Science. ${ }^{38} \mathrm{Az}$ oklevélbe kerülő végzettség mindkét szinten informatikus könyvtáros, mesterszinten okleveles informatikus könyvtárosként megkülönböztetve (MA-ban elválik a könyvtártudomány szakelnevezéstől). Az eddigi szakmai diskurzusok során nem sikerült új, a nemzetközi trendekhez igazodó, a magyarországi köztudatban pontosan érthető, minden fél számára elfogadható, a jelenleginél célszerübb szakelnevezést meghatározni. ${ }^{39}$

\section{Téves állitás: A levelezõ képzés kizárólag önköltséges formában végezhetō.}

Információhiány tapasztalható az államilag finanszírozott félévekről: a nemcsak nappali, hanem levelezö tagozaton is állami ösztöndíjjal támogatott finanszírozási formában végezhető BA és MA képzésről - a 2006 előtt, föiskolán vagy egyetemen végzett személyek esetében a még rendelkezésre álló állami ösztöndíjjal támogatott félévek száma rendszerint elegendő ahhoz, hogy a mesterszakot, akár levelező tagozaton is állami ösztöndíjjal támogatott finanszírozási formában végezhessék el. 12 állami ösztöndíjjal támogatott félév áll rendelkezésére a hallgatónak. 2006 elött végzettek esetében - amennyiben nem merült fel költségtérítés fizetése a diplomaszerzésig - 7 félév „elhasználását” vélelmezi a rendszer, így a speciális esetektől eltekintve rendszerint még 5 félév áll az érdeklődők rendelkezésére, ami elegendő a mesterszak (4 félév nappali és levelező tagozaton egyaránt) elvégzéséhez, de egy híján az alapszakhoz (6 félév) is. ${ }^{40}$

\section{Téves állitús: A kétszakosság megszünése miatt nincs kompromisszumos meg- oldás más szakterület tanulmányozására.}

Az alapképzésben a kétszakosság „pótlására” kínálkozó lehetőségek: alapszakos minor (informatikus könyvtáros BA specializáció helyett más szak 50 kredites

${ }^{38}$ L. pl.: Hjørland, Birger: Library and Information Science (LIS). = ISKO Encyclopedia of Knowledge Organization. Eds. Hjørland, Birger - Gnoli, Claudio. http://www.isko.org/cyclo/ lis; Frascati Manual. OECD. http://www.oecd.org/sti/inno/frascati-manual.htm; Library and Information Science. Journal Rankings. SJR - Scimago Journal \& Country Rank. https://www. scimagojr.com/journalrank.php?category=3309; Master Journal List. Scope Notes. Social Science Citation Index (SSCI). Web of Science (WoS). http://mjl.clarivate.com/scope/scope_ssci/\#WU

${ }^{39}$ A képzés- és terminológiafejlesztéssel kapcsolatos nemzetközi szakmai diskurzusokat 1 : IFLA Education and Training Section. https://www.ifla.org/set; IFLA Building Strong Library and Information Science Education (BSLISE) Working Group. https://bslise.org

${ }^{40}$ „A támogatási idő számítási algoritmusának eredményeit a hallgató egy részletes riport formájában elérheti a Magyarország.hu portálon ügyfélkapus hozzáféréssel, hogy a FIR az intézmények által bejelentett adatok alapján mekkora támogatási idő felhasználást számított ki (https:// ugyintezes.magyarorszag.hu/szolgaltatasok/fir.html). Ennek érdekében valamelyik okmányirodában személyesen szükséges regisztrálni az Ügyfélkapu szolgáltatásra.” Forrás: Hallgatói útmutató. A támogatott félévek számításának alapjai a FIR-ben. 3. p. http://www.felvi.hu/pub_bin/dload/ felsooktatasimuhely/FIR_fuzet_06_Tamido_szamitas_HLG_20150131.pdf 
modulja vagy fordítva, kiemelkedő hallgatók esetében kredit-túlfutási díjfizetés nélkül, honorácior státuszban a specializáció és minor is egyaránt végezhetö ${ }^{41}$ ) vagy posztgraduális MA képzés (a mesterképzésre nem csak föiskolai szintü vagy alapszakos könyvtáros - szakirányú - diploma birtokában jelentkezhetnek az érdeklődők, hanem kreditelismertetési eljárás, illetve részismereti képzés ${ }^{42}$ után más szakokról is lehetséges a bemenet). A diszciplináris képzésben a kétszakosság megszünése miatti ür betöltése érdekében igyekeztünk a lehető legszélesebb MA bemenetet meghatározni: nem informatikus könyvtáros alapképzési szakról, továbbá nem a korábbi főiskolai szintủ könyvtáros, informatikus könyvtáros szakokról érkezők számára a szükséges 30 kreditből 8 (társadalomés bölcsészettudományok területéről legalább 2 kredit; könyvtártan és információszervezés, menedzsment ismeretek területéről legalább 2 kredit; informatika területéről legalább 2 kredit; kommunikációs ismeretek területéről legalább 2 kredit) követelhető meg a felvételhez, majd a hiányzó 22 kredit megszerzésére a KKK szerint a képzés során van lehetőség: „A mesterképzésbe való felvétel feltétele, hogy a hallgató legalább 8 kredittel rendelkezzen. A hiányzó krediteket a felsőoktatási intézmény tanulmányi és vizsgaszabályzatában meghatározottak szerint meg kell szerezni."

A könyvtárostanár osztatlan tanárképzés szakpárban végezhető.

\section{Téves állitás: A képzésekben nem jelennek meg a speciálisan az egyetemi könyvtárakban történö munkavégzést segítö ismeretek.}

A képzések valamennyi könyvtártípusban történő munkavégzésre készítenek fel, nem lehet kiemelni egyetlen gyüjteményfajtát sem. Arra sincs mód, hogy önálló „egyetemi könyvtáros” specializáció induljon, hiszen a hallgatói létszámok jelenleg korlátoznak bennünket. (Amennyiben az egyetemi könyvtárak egy specializáció indítását lehetővé tévő létszámban beiskoláznák dolgozóikat, esély nyílhatna erre.) A hallgató természetesen többféle módon specializálódhat, akár kötelezően, akár szabadon választható kurzusokkal, szemináriumi, szakdolgozati témaválasztással, OTDK szerepléssel stb. Büszkék vagyunk arra, hogy számos végzettünk egyetemi könyvtárakban dolgozik, köztük az ELTE EKSZ valamely gyüjteményében.

${ }^{41}$ „A honorácior státusz karunk legtehetségesebb hallgatóinak, minden képzési formában (BA, MA, osztatlan tanári szak) lehetőséget biztosít arra, hogy 50 kredit értékben egy plusz minort, szakirányt vagy adott tanulmányi érdeklődést, avagy kutatási területet szem előtt tartva, egy megalapozottan összeválogatott tanegységlistát, kötelező szakos tanulmányai mellett, megfelelő tanulmányi átlag szinten tartása mellett térítésmentesen elvégezhessen." Forrás: Pályázati kiírás honorácior státusz elnyeréséhez 2019-2020. ösz. ELTE BTK HÖK. https://btkhok.elte.hu/wpcontent/uploads/2019/09/honor\%C3\%A1cior_ki\%C3\%ADr\%C3\%A1s2019-20\%C5\%91sz.pdf

${ }^{42}$ Részismereti képzések. ELTE BTK. https://btk.elte.hu/reszismereti-kepzesek 


\section{Zászlóra tüzve}

Winkler Bea állatorvosegyetemi könyvtárigazgatóval közösen készített, a The Journal of Academic Librarianship hasábjain Academic libraries as the flagships of publishing trends in LIS: a complex analysis of rankings, citations and topics of research címmel ${ }^{43}$ megjelent közleményünk a könyvtár- és információtudomány nemzetközi porondján is minden kétséget kizáróan alátámasztja az egyetemi könyvtárügy iránti elkötelezettségünket. Newton III. törvényét elfogadva, a két fél kölcsönös érdeke, hogy ez a lojalitás a szakma részéröl a felsőfokú könyvtárosképzés irányába is folyamatosan érezhetö legyen.

\section{Rezümé}

A multifunkciós kihívásokkal szembesülő, piacgazdasági keretek között működő könyvtári hálózat tagjai nem láthatják el küldetésüket sokoldalúan felkészült könyvtárosok nélkül, ugyanakkor a képző- és továbbképzőhelyek sem a könyvtárügytől elszigetelten. A tanulmány elemzi a közelmúlt - felsőfokú könyvtárosképzést is érintő - meghatározó könyvtárszakmai tényezőit, és megvilágítja az egyetemi könyvtárakkal kapcsolatos nemzetközi és hazai trendeket. A tudásalapú gazdaság, annak pénzügyi környezete és az egyetemi könyvtárak által támasztott követelményekre reagálva az Eötvös Loránd Tudományegyetem könyvtárosképzését fókuszba helyezve, értékeli a felsőoktatás multidiszciplináris kompetenciafejlesztésre adott válaszait: az elmélet és a gyakorlat szinergikus viszonyának fokozására irányuló törekvéseket, a könyvtár- és információtudományi kutatások innovációtámogató eredményeit. A közlemény - a képzéssel kapcsolatban felmerülő téves véleményekből válogatva, azokra reagálva - feltárja a napjainkban az egyetemi könyvtárakban is tapasztalható könyvtáros munkaerőhiány (pályaelhagyás) okait, rögzíti a sürgető beavatkozási, illetve együttműködési területeket, melyeknek financiális és további (akár információhiányból fakadó) háttere egyaránt azonosítható.

\section{Multidisciplinary tertiary level librarian training and multifunctional university libraries in the context of a knowledge-based economy}

Facing multifunctional expectations and operating in market economies, members of the library network cannot fulfil their mission without sufficiently prepared, multi-skilled librarians; furthermore, educational establishments cannot function in isolation from librarianship. This paper analyses the most recent decisive factors of the librarian profession which have an effect on the higher education of librarians as well, and clarifies international and domestic trends related to university libraries. Reacting to the requirements

${ }^{43}$ Winkler, Bea - Kiszl, Péter: Academic libraries as the flagships of publishing trends in LIS: a complex analysis of rankings, citations and topics of research. $=$ The Journal of Academic Librarianship, 46. vol. 2020. 5. no. https://doi.org/10.1016/j.acalib.2020.102223 
of our knowledge-based economy, its financial environment and university libraries, and focusing on the librarian training programme of Eötvös Loránd University in particular, the paper also evaluates how post-secondary education responded to multidisciplinary competence development. It especially highlights the efforts aimed at enhancing the synergic relationship between theory and practice, and the results of research in the field of library and information science which support innovation. The study, enumerating and responding to some of the false perceptions related to the training programme, reveals the reasons behind labour shortage (career changes) among librarians, which affects university libraries as well, and identifies areas in need of urgent intervention and cooperation, the backgrounds of which - financial and otherwise (potentially also arising from a lack of information) - are also described.

KISZL PÉTER

intézetigazgató

ELTE Eötvös Loránd Tudományegyetem Bölcsészettudományi Kar

Könyvtár- és Információtudományi Intézet

ORCID: 0000-0003-2992-295X 